\title{
EXTRACTION OF TRITIUM FROM LITHIUM ALUMINATE TARGETS
}

\author{
A. A. KISHBAUGH
}

cuassification canceurid with de litions

BY AUTHDRITY OF

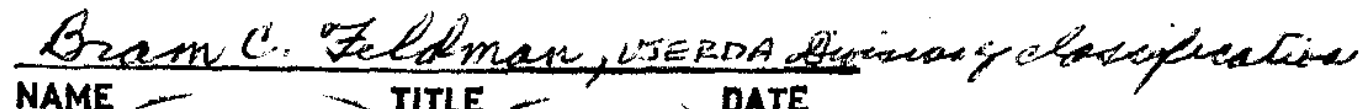
NAME - TITLE gan10,1975- P\&M 5-1-75

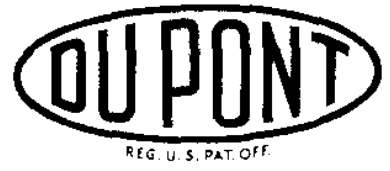

Savannah River Laboratory

Aiken, South Carolina 


\section{LEGAL NOTICE}

This report was prepared as an account of Government sponsored work. Nelther the Untted States, nor the Commission, nor any person acting on behalf of the Commission:

A. Makes any warranty or representation, expressed or implied, with respect to the accuracy, completeness, or usefulness of the information contained in this report, or that the use of any information, apparatus, method, or process disclosed in this report may not infringe privately owned rights; or

B. Assumes any liabllities with respect to the use of, or for damages resulting from the use of any Information, apparatus, method, or process disclosed in this report.

As used in the above, "person acting on behalf of the Commission" includes any employee or contractor of the Commission, or employee of such contractor, to the extent that such employee or contractor of the Commission, or employee of such contractor prepares, disseminates, or provides access to, any information pursuant to his employment or contract with the Commission, or his employment with such contractor. 


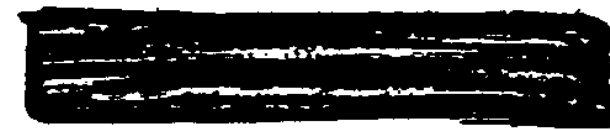

EXTRACTION OF' TRITIUM FROM

LITHIUM ALUMINATE TARGETS

by

Albert A. Kishbaugh

SRL FILE COPY

Approved by

D. S. Webster, Research Manager

Separations Englneering Division

August 1966

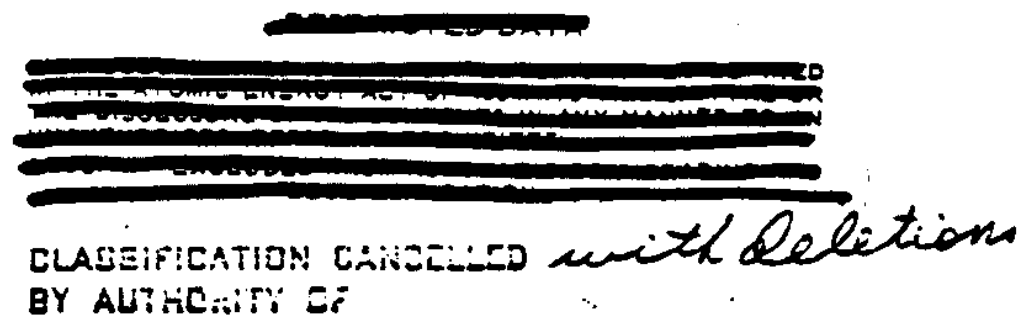

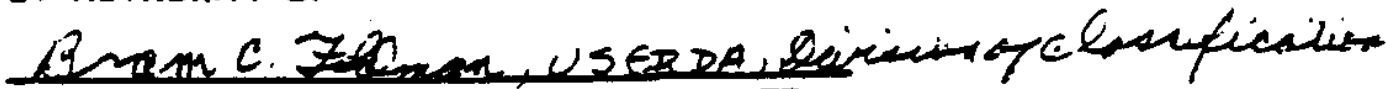
NAME

Son 10,19.75 TITy on 5-1-75

M. I. DU bONT DE KEMOURS \& COMPANY

SAVANNAH RIVER LAGORATORY

AIKEN, S C. 20001

CONTRACT ATTO7.2.1 WTH THE

UNITED STATES ATOMIC ENERCY COMMISSION

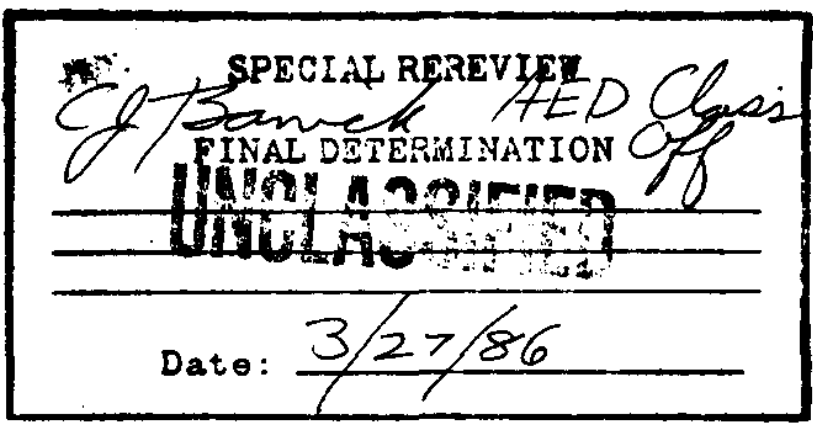




\section{ABSTRACT}

mitium can be extracted satispactorily from I1thium alunisate targets by heating at $850^{\circ} \mathrm{C}$ In a vacuum for 10 hours; less than $0.1 \%$ of the tritium remains in the residue.

Page

List of pables and Figures . . . . . . . . . . . . . 111 Introduct1on . . . . . . . . . . . . . . . . 1 Summary . . . . . . . . . . . . . . . . . . . I 1 D1scussion . . . . . . . . . . . . . . . . . 2

Experimental Apparatus . . . . . . . . . ...... 2

Experimental Procedure ................ 3

Extraction Crele ................. 31

Eopcal1te-zeollte Systom ............ 4

Res1due Analjsis . . . . . . . . . . . . 5

Criterion for Sat1sfactory Extraction.......... 5

Target Descript1on . . . . . . . . . . . 6

Results...................... 6

Elimination of flux . . . . . . . . . . . . . 6

Temperature and Time Requirements......... 7

Isotop1c Pur1ty . . . . . . . . . . . . . 8

Material of Construction for crucible........ 9

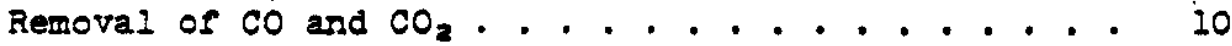

Future Work .................. 10

Append1x A - Deta1led Sumary of Data Obta1ned........ 11

Appendix B - Extraction of Tr1t1um srom isthium Aluminate

Targets Using Flux............. 25 


$$
\text { DP-1058, Del. }
$$

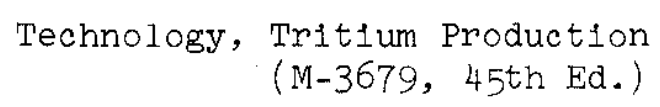

EXTRACTION OF TRITIUM FROM

LITHIUM ALUMINATE TARGETS

by

Albert A. Kishbaugh

Approved by

D. S. Webster, Research Manager

Separations Engineering Division

August 1966

classification cancelled with Qeletion.

BY AUTHORITY OF

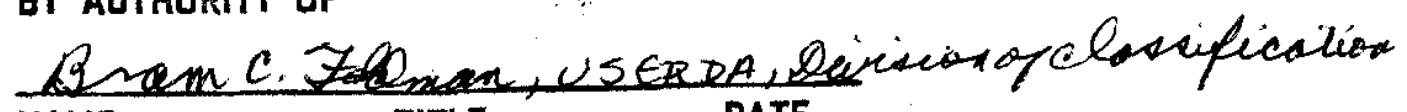
NAME

Sen 10,1975 Th 5 - $1-75$

PE. I. DU PONT DE ḰEMOURS \& COMPANY

SAVANNAH RIVER LABORATORY

AIKEN, S. C. 29801

CONTRACT AT(07-2)-1 WITH THE

UNITED STATES ATOMIC ENERGY COMMISSION 


\section{ABSTRACT}

Tritium can be extracted satisfactorily from Iithium aluminate targets by heating at $850^{\circ} \mathrm{C}$ In a vacuum for 10 hours; less than $0.1 \%$ of the tritium remains in the residue.

\section{CONTENTS}

$\underline{\text { Page }}$

List of Tables and Figures................. 111

Introduction . . . . . . . . . . . . . . . . 1

Summary . . . . . . . . . . . . . . . . . . 1

Discussion . . . . . . . . . . . . . . . . 2

Experimental Apparatus . . . . . . . . . . . 2

Experimental Procedure ............... 3

Extraction cycle ................ 3

Hopcalite-Zeolite System ............ 4

Restulue Analysis ............... 5

Criterion for Satisfactory Extraction.......... 5

Target Description .............. 6

Results................... 6

Elimination of Flux............... 6

Temperature and Time Requirements . . . . . . . 7

Isotopic Purity . . . . . . . . . . . . . . . 8

Materlal of Construction for Crucible....... 9

Removal of $\mathrm{CO}$ and $\mathrm{CO}_{2}$.............. 10

Future Work . . . . . . . . . . . . . 10

Appendix A - Detailed Summary of Data Obtained . . . . . . 11

Appendix B - Extraction of Tritium from Lithium Aluminate

Targets Using Flux .......... 25 


\section{LIST OF TABLES AND FIGURES}

Table

Page

I Tritium Loss to the Residue . . . . . . . . . 8

II Thermal Diffusion Column Capac1ty . . . . . . . 9

II Gases Evolved from Crucibles of Stainless steel and Carbon Steel . . . . . . . . . . . . . . . . 9

IV Summary of Tests . . . . . . . . . . . . 12

V Run 8: Gases Evolved from Irradiated Target in Flux at $850^{\circ} \mathrm{C}$ for 20 Hours - Carbon Steel Crucible . 14

VI Run 9: Gases Evolved from Irradiated Target at $850^{\circ} \mathrm{C}$ for 21 Hours - Carbon Steel Crucible . . . . 15

VII Run 1I: Gases Evolved from Irradiated Target in Pre-Treated Flux at $850^{\circ} \mathrm{C}$ for 20 Hours - Carbon Steel Crucible ............... 16

VIII Run 12: Gases Evolved from Irradiated Target in Pre-Treated Flux at $850^{\circ} \mathrm{C}$ for 24 Hours - Carbon Steel Cructble . . . . . . . . . . . . 17

IX Run 13: Gases Evolved from Irradiated Target at $900^{\circ} \mathrm{C}$ for 24 Hours - 304L Stainless Steel Cructble . 18

$X \quad$ Run 14: Gases Evolved from Irradiated Target at $850^{\circ} \mathrm{C}$ for 11 Hours - $304 \mathrm{~L}$ Stainless Steel Crucible . 19

XI Run 15: Gases Evolved from Irradiated Target at $750^{\circ} \mathrm{C}$ for 11 Hours - 304L Stainless Steel Crucible . 20

XII Run 16: Gases Evolved from Irradiated Target at $850^{\circ} \mathrm{C}$ for 6 Hours - $304 \mathrm{~L}$ Stainless Steel Crucible . 21

XIII Runs 17, 18, 19 and 22: Gases Evolved from Carbon and Stainless Steel Crucibles at $850^{\circ} \mathrm{C}$. . . . . 22

XIV Run 21: Gases Evolved from Irradiated Target at $750^{\circ} \mathrm{C}$ for 11 Hours $-304 \mathrm{~L}$ Stainless Steel Crucible . 23

F1gure

I Schematic Diagram of Extraction Fac1lity . . . . . 2

2 Photograph of Extraction Fac1lity . . . . . . . 3

3 Procedure for Removal of $\mathrm{CO}+\mathrm{CO}_{2}$ from Product . . . . 4

4 Gases Evolved at $900^{\circ} \mathrm{C}$ - No Flux (Run 13) . . . . . 7

5 Proposed Flowsheet for Extraction Process with Flux. 25

6 Gases Evolved at $850^{\circ} \mathrm{C}$ - W1th Flux (Run 12) . . . 26 
7 Extent of Ceramic D1ssolution at End of Run 5. . . 27

8 Extent of Ceramic Dissolution at End of Run 4 . . . 28

$9 \mathrm{H}_{2} \mathrm{O}$ Left in $\mathrm{Na}_{2} \mathrm{~B}_{4} \mathrm{O}_{7}$ as a Function of Time at $850^{\circ} \mathrm{C}$ in a Vacuum ................. . . 29

10 Internal View of Furnace Showing Decomposed $\mathrm{Na}_{2} \mathrm{~B}_{4} \mathrm{O}_{7} \cdot 29$

11 Extent of Ceramic D1ssolution at End of Run 6. . . 31 


\section{EXTRACTION OF TRITIUM FROM LITHIUM ALUMINATE TARGETS}

\section{INTRODUCTION}

The New Production Reactor (NPR) at Hanford requires tritiumproducing targets that will not melt even in the event of acc1dents that might ralse the temperature of the zirconium-clad targets to an estimated $1100^{\circ} \mathrm{C}$. Lithium aluminate was chosen as the most suitable target material ( $\mathrm{mp}=1900^{\circ} \mathrm{C}$ ) after tests of Its Irradiation behavior.

Pacific Northwest Laboratory (PNL) proposed extraction of tritium from the de-clad lithium aluminate targets by dissolution in molten sodium tetraborate at $850^{\circ} \mathrm{C}$, since preliminary data indicated that thermal extraction of the tritium without the use of a flux would give high losses to the residue. The Savannah River Laboratory (SRL) was asked to evaluate the proposed process for use at the Savannah RIver Plant (SRP) --- PNL does not have facilities for large scale tests with irradiated targets. Experiments with both irradiated and unirradiated targets, with and without flux, were conducted at SRL to obtain sufficient information to estimate the cost of modifying existing tritium separations equipment for extraction of the NPR ceramic targets. The results of these tests are presented in this report.

\section{SUMMARY}

Experiments conducted at SRL to evaluate a process for extracting tritium from lithlum aluminate targets showed that:

- The targets do not have to be dissolved in flux to extract the tritium; in fact, the use of flux results in a 1 to $2 \%$ loss of tritium to the residue.

- The tritium can be extracted from the targets by heating at $850^{\circ} \mathrm{C}$ in a vacuum for 11 hours, with less than $0.1 \%$ tritium lost to the residue. Use of a lower extraction temperature increases the loss of tritium in the residue; for example, 11 hours at $750^{\circ} \mathrm{C}$ resulted in a $1.2 \%$ loss.

- The 1sotopic purity of tritium in the feed to the plant thermal diffusion columns is expected to be in the range of 50 to $80 \%$. The impurity is protium derived from $\mathrm{H}_{2} \mathrm{O}$ present in the ceramic and on the crucible; the evolved water vapor will be decomposed on an existing uranium bed. 
- $\mathrm{CO}$ and $\mathrm{CO}_{2}$ evolved from the ceramic during extraction add a volume equivalent to one-tenth to one-third that of the tritium.

- The hydrogen isotopes can be separated from most of the $\mathrm{CO}$ and $\mathrm{CO}_{2}$, if necessary, with Hopcal1te* (oxidizer) and zeolite (water absorber) beds in. series. This treatment w1ll be used only if current studies show that the effectiveness of the plant uranium decomposer and/or the palladium diffuser is reduced by these gases.

\title{
DISCUSSION
}

\section{EXPERIMENTAL APPARATUS}

The pilot-scale tritium extraction equipment used for these tests is illustrated schematically in Figure 1. The apparatus consisted of a vacuum furnace capable of heating a l-foot target element and the required flux to a temperature of $1000^{\circ} \mathrm{C}$, a combination of Hopcalite (oxidizer) and zeolite (water absorber) beds in series for separating the isotopes of hydrogen from the other extraction gases, a uranium bed used for a decomposer, a specially bullt vacuum pump with a limited collection volume on the discharge side (to permit accurate measurements of small gas volumes), and gas collection vessels. Pressures were measured

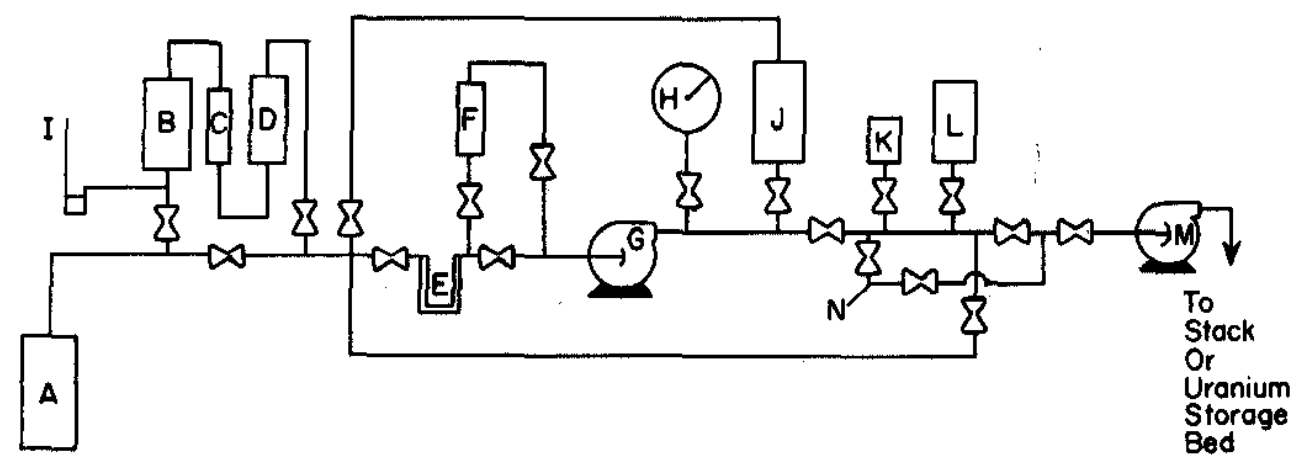

\begin{abstract}
A - Extraction Furnace
B. "Hopcalite" Bed

C. Cooling Water Jacket

D. Zeolite Bed

E - Cold Trap.
\end{abstract}

F. Uranium Bed Decomposer

G - Special Vacuum Pump

H . 0. $150 \mathrm{em} \mathrm{Hg} \mathrm{Ashcroft} \mathrm{Cage}$

I - Closed End Manometer

J. 8339-cc Collection Vessel
K - 33.2-cc Collection Vessel $L$ - 77.6-cc Collection Vessel M- Modified Welch "Duo-Seal" N. Somple Point Pump

FIG. I SCHEMATIC DIAGRAM OF EXTRACTION FACILITY

* Hopcalite is the registered trademark of Mine Safety Appliances Co. for chemical materials for use as a catalyst. 
with an 8-inch-diameter $0-150 \mathrm{~cm} \mathrm{Hg}$, pressure-vacuum gage. A trap cooled with liquid nitrogen was included between the furnace and the pump to collect all gases condensable at $-77^{\circ} \mathrm{C}$. A Welch "Duo-Seal" vacuum, pump, modified by W. M. Welch Scientific Company to be leaktight on both the vacuum and discharge sides, was used to transfer gases from the collectors to either the stack or a uranlum storage bed. All apparatus was of metal except for tine glass cold trap and sample bulbs. The furnace was shielded to protect personnel against radiation, and all equipment was enclosed in a ventilated glovebox. Figure 2 is a photograph of the complete facility.

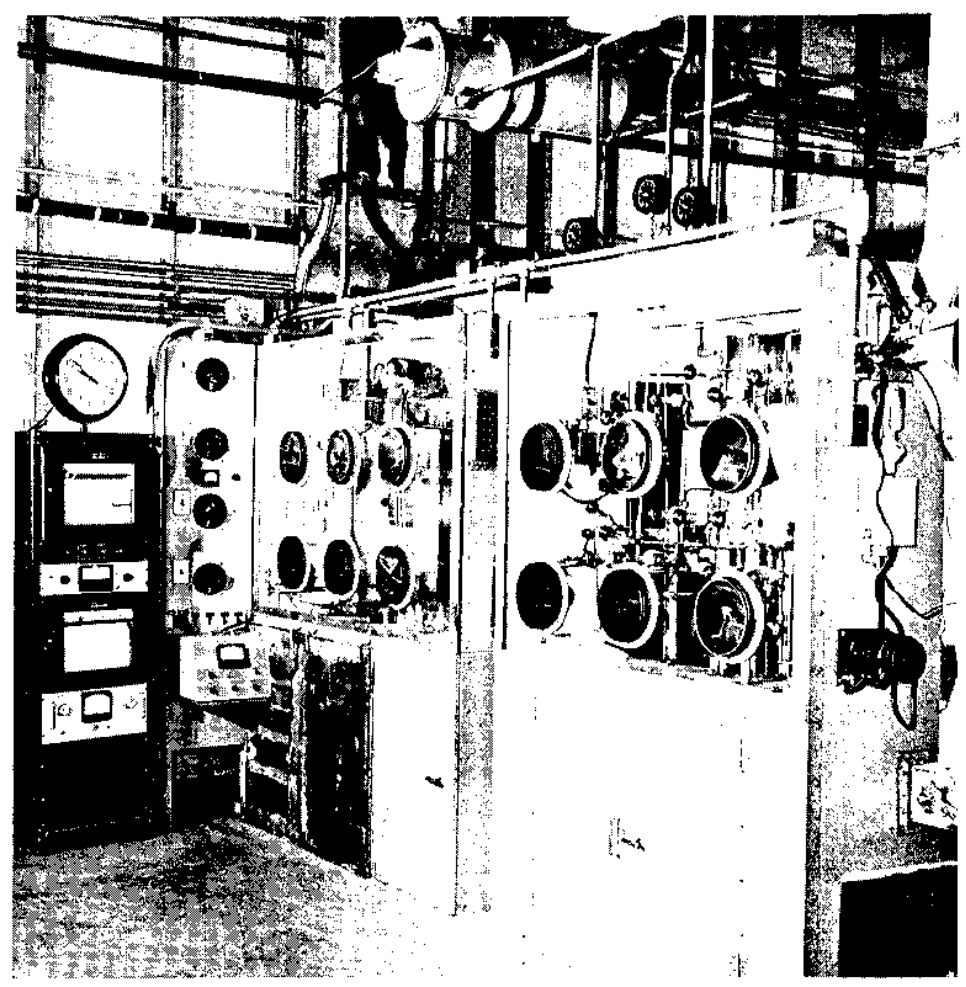

FIG. 2 PHOTOGRAPH OF EXTRACTION FACILITY

\section{EXPERIMENTAL PROCEDURE}

\section{Extraction Cycle}

The extractions were made with various charges to the furnace to study the effects of the following variables: ratio of flux to target, pretreatment of flux, location of target in flux, material of construction of crucible, and time for extraction at various temperatures. After loading the furnace and pumping the 
stem down to less than 50 microns, a normal extraction cycle started with a 2-hour furnace heatup perlod to the desired extraction temperature. The gases evolved were passed through one or more of the following systems, depending on the desired results: Hopcalite-zeolite beds, cold trap, and uranium decomposer. All gases were collected in callbrated volumes at known temperature and pressure, and were analyzed by mass spectrometry.

When the cold trap was used, it was warmed to room temperature at the completion of the extraction cycle and the gases

evolved were collected and sampled for analys1s. Further heating of the trap, to about $100^{\circ} \mathrm{C}$, evolved the water vapors $\left(\mathrm{H}_{2} \mathrm{O}\right.$, HTO, $\mathrm{T}_{2} \mathrm{O}$ ), which were pumped through the uranium decomposer at $550^{\circ} \mathrm{C}$, collected, and analyzed.

At the completion of each run with irradiated targets the equipment was rinsed with hydrogen at elevated temperatures to remove tritium absorbed on the walls. The tritlum collected in the rinse was added to that collected during the run.

\section{Hopcalite - zeolite System}

The Hopcalite ( $88 \mathrm{~g}$ of an $80 / 20$ mixture of manganese dioxide and cupric oxide) and zeolite $(61 \mathrm{~g}$ of Linde Molecular Sieve Type $3 A$ ) beds were used during two runs to demonstrate a method of separating the hydrogen isotopes from the majority of the other gases. The system is illustrated schematically in Figure 3.

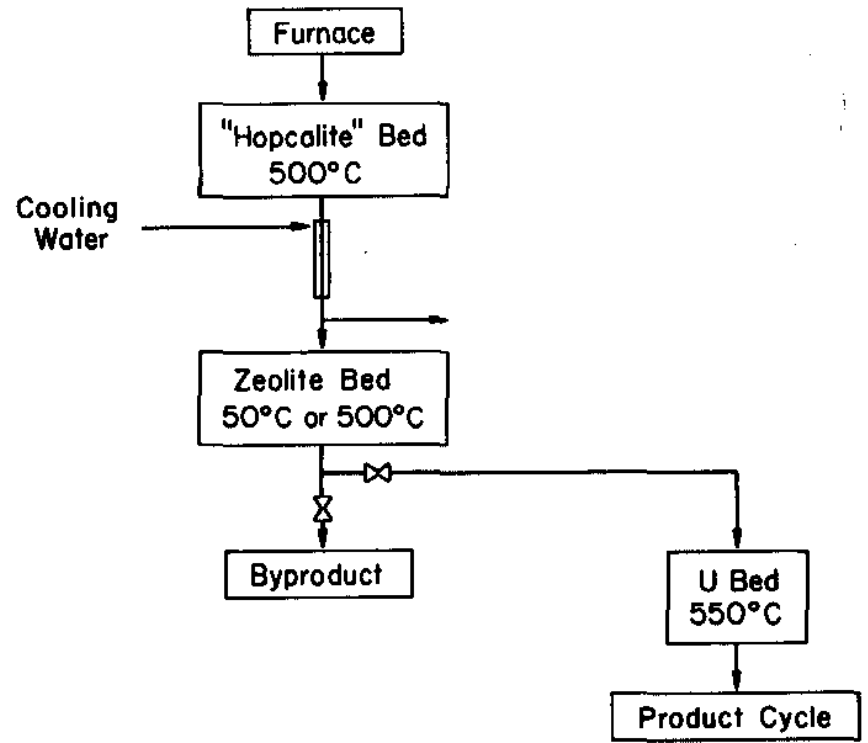

FIG. 3 PROCEDURE FOR REMOVAL OF $\mathrm{CO}+\mathrm{CO}_{2}$ FROM PRODUCT 
The gases evolved from the furnace were passed through the Hopcalite bed at $500^{\circ} \mathrm{C}$ to oxidize the hydrogen 1sotopes. The vapors were then sorbed on the zeolite bed, which was maintained at $50^{\circ} \mathrm{C}$ during the extraction cycle, while the remaining gases (mainly $\mathrm{He}, \mathrm{CO}$, and $\mathrm{CO}_{2}$ ) were collected, sampled, and discharged to the stack. At the completion of the extraction cycle, the zeolite bed was heated to $500^{\circ} \mathrm{C}$ for desorption, and the water vapors. were passed through a uranium $(185 \mathrm{~g} \mathrm{U})$ bed decomposer at $550^{\circ} \mathrm{C}$ to produce the gaseous hydrogen isotopes.

\section{Residue Analysis}

Several methods were used to measure the tritium content of the residues. The residue from runs made using flux was sampled at various locations in the crucible; each sample was dissolved in bolling $5 \mathrm{M} \mathrm{HCl}$ in a closed system. Gases evolved during the dissolution were sampled and analyzed by mass spectrometry. The HCI solution was decomposed with calclum metal and the resulting hydrogen was analyzed for tritium by an ion chamber.

Residues from the runs in which no flux was used were analyzed by two methods: (1) A 4 to $6 \mathrm{~g}$ sample of the residue was dissolved in a closed system by a 50-50 mixture of concentrated $\mathrm{H}_{2} \mathrm{SO}_{4}$ and concentrated $\mathrm{H}_{3} \mathrm{PO}_{4}$; the gas phase was analyzed by mass spectrometry and the liquid phase was diluted, decomposed with calcium, and the gases were analyzed for tritium by ion chamber. (2) A 0.5 to $0.9 \mathrm{~g}$ sample of the residue was heated to $1400^{\circ} \mathrm{C}$ in a closed system under vacuum, and the evolved gases were collected and analyzed directly in the ion chamber. Results by the second method of analysis showed significant variation between several samples from one pellet, whereas good agreement was obtained using the first method. The necessity of using small samples for the second method probably prevented representative sampling. Only analyses obtained by the first method are presented in this report.

\section{CRITERION FOR SATISFACTORY EXTRACTION}

Product loss in the residue was used as the sole criterion for satisfactory extraction of tritium during a run. Normally the tritium content of a target at the time of extraction is calculated from the helium quantity: $c c \mathrm{~T}_{2}=1 / 2\left(c c{ }^{4} \mathrm{He}-c c{ }^{3} \mathrm{He}\right.$ ). However, the targets used in these studies were vacuum-tested for cladding leaks after fabrication by introducing ${ }^{4} \mathrm{He}$ into the target through a small hole in the end cap, and sealing the hole. The excess ${ }^{4}$ He varied from target to target thus making it Impossible to obtain the normal material balance after extraction. 
Estimates of the degree of lithium burnup in the reactor similarly were not precise enough to provide a reliable indication of recovery performance. Further error was introduced by adsorption of tritium on the walls of the equipment, an effect that was accentuated by the very low tritium content of the targets (average $\mathrm{T}_{2}$ GVR $=0.63 \mathrm{STP} \mathrm{cc} / \mathrm{cc}$ ceramic). In contrast, the tritium content of the residue can be measured accurately to less than $0.1 \%$ of the total tritium.

\section{TARGET DESCRIPTION}

The unirradiated targets used for these tests consisted of an aluminum housing tube, 13 inches long by 1-1/4 inches OD, containing pellets of lithium aluminate 2 to $2-1 / 2$ inches long and $1-3 / 32$ inches in diameter. The density of the pellets was $2.33 \mathrm{~g} / \mathrm{cc}$ ( $89 \%$ of theoretical).

The irradiated targets were similar to the unirradiated targets except that they were only 12 inches long and the density of the pellets averaged about $2.07 \mathrm{~g} / \mathrm{cc}(79.3 \%$ of theoret1cal). The zirconium jackets that were present over the aluminum during irradiation were removed at Hanford before shipping.

\section{RESULTS}

The data for all of the runs are summarlzed in Table IV of Appendix A, which gives the conditions for each run, the overall gas composition in terms of the major gases evolved, and the tritium content of the residues. Tables $V$ through XIV of Appendix A list in detall the composition of the gases evolved at varlous times during extraction of the irradiated NPR ceramic targets. observations made during the tests are discussed below.

\section{Elimination of Flux}

Before the irradiated targets were received, a falrly extensive preparatory study was made of the dissolution of lithium aluminate in sodium tetraborate, in accordance with the original process concept. Subsequent tests made with irradiated targets showed that flux was not needed to recover the tritium, so the remainder of the program was concentrated on the thermal extraction of tritium without the use of flux; only these nonflux runs will be discussed in the main section of this report. The preliminary studies made with flux and unirradiated targets before recelpt of the irradiated targets are presented in Appendix $B$. 


\section{Temperature and Time Requirements}

Figure 4 shows the rate at which gases are evolved during a typical extraction (no flux) in a stainless steel crucible (Run 13). As the crucible was heated to the desired temperature for

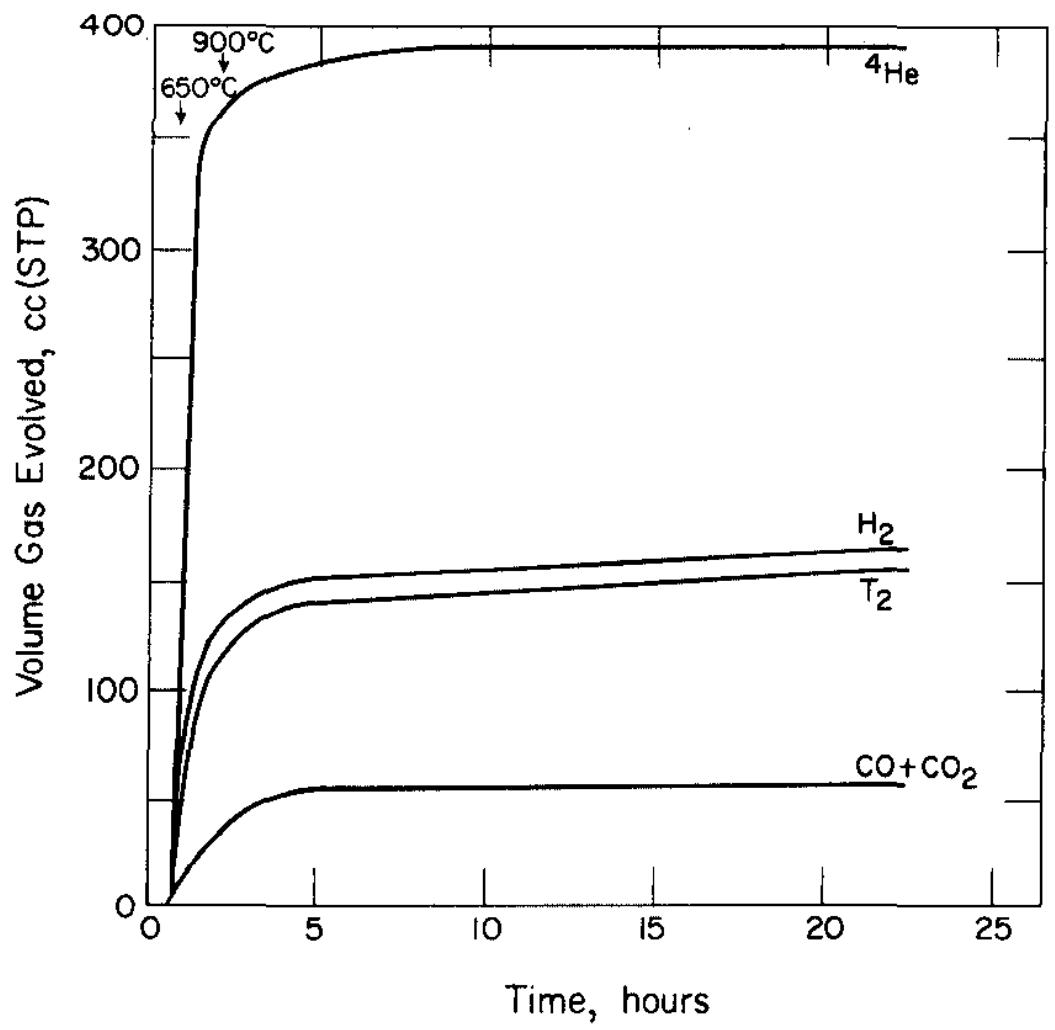

FIG. 4 GASES EVOLVED AT $900^{\circ} \mathrm{C}$ - NO FLUX (Run 13)

extraction $\left(900^{\circ} \mathrm{C}\right.$ in Run 13$)$, the aluminum can melted $\left(\sim 660^{\circ} \mathrm{C}\right)$ releasing an initial surge of ${ }^{4} \mathrm{He}, \mathrm{H}_{2}, \mathrm{~T}_{2}$, and $\mathrm{CO}+\mathrm{CO}_{2}$. After 8 hours of heating, with about 6 hours at extraction temperature, the evolution of ${ }^{4} \mathrm{He}$ stopped and the rate of $\mathrm{H}_{2}, \mathrm{~T}_{2}$, and $\mathrm{CO}+\mathrm{CO}_{2}$ evolution decreased rapidly. As indicated by the residue analyses in Table I, more than $99.9 \%$ of the product had been extracted from the target in 6 to 11 hours; the $\mathrm{H}_{2}$ and $\mathrm{T}_{2}$ recovered after that time is gas that was absorbed on the walis of the metal equipment during the initial surge and was subsequently vacuum outgassed. The $\mathrm{CO}$ and $\mathrm{CO}_{2}$ evolved are from both target and crucible.

At the completion of a run the pellets were brittle and easily cracked along their axes; higher temperatures of extraction increased the brittleness. 


\section{TABLE I}

Tritium Loss to the Residue

\begin{tabular}{rll} 
Run & Condition & \multicolumn{1}{c}{$\begin{array}{c}\text { Tritium Loss } \\
\text { to Res1due, (a) }\end{array}$} \\
\cline { 2 - 3 } 13 & 24 hours at $900^{\circ} \mathrm{C}$ & 0.004 \\
9 & 21 hours at $850^{\circ} \mathrm{C}$ & 0.012 \\
14 & 11 hours at $850^{\circ} \mathrm{C}$ & $0.008(\mathrm{~b})$ \\
16 & 6 hours at $850^{\circ} \mathrm{C}$ & $0.36(\mathrm{c})$ \\
15 & 11 hours at $750^{\circ} \mathrm{C}$ & 0.91 \\
21 & 11 hours at $750^{\circ} \mathrm{C}$ & 1.5 \\
20 & Residue from Run 15,6 hours at $850^{\circ} \mathrm{C}$ & 0.012 \\
23 & Residue from Run 21,6 hours at $850^{\circ} \mathrm{C}$ & 0.008
\end{tabular}

(a) Based on tritium recovered.

(b) Believed to be low by a factor of 10 .

(c) Average of $0.41,0.32$, and $0.36 \%$, the analyses obtained from three different peliets.

The residue analyses for the runs using irradiated targets and no flux, summarized in Table I, show that tritium can be satisfactorily extracted from lithium aluminate targets in, at most, 11 hours at $850^{\circ} \mathrm{C}$ (Runs 14 and 16 ). In runs 15 and 21 the target was heated to only $750^{\circ} \mathrm{C}$ for 11 hours; the resulting average loss of $1.2 \%$ is considered too high for normal plant production runs $(<0.1 \%)$, but should be low enough to permit a fullscale extraction test in the separations plant.

\section{Isotopic Purity}

The capacity of the plant thermal diffusion columns for separating hydrogen from tritium decreases considerably as the tritium concentration in the feed decreases, as shown in Table II. The isotopic purity of the extraction gases during the nonflux runs varied from 15 to 46\%, with 15 to $20 \%$ of the tritium present as HTO and $\mathrm{T}_{2} \mathrm{O}$ (Runs 9, 16, 21). As noted in the next section, most of the protium comes from the crucibles. Furthermore, all of these runs were made with tritium GVR's (ratio, volume of gas at STP to volume of target) varying from 0.25 to 0.95 , whereas the expected production targets for the plant will have a tritium GVR of about 1.2. Because the hydrogen content (water) of the production targets is expected to be lower than that of the targets used in this study, the 1sotoplc purity for the plant feed to the thermal diffusion columns should be in excess of 50 to $60 \%$. (The water content of targets currently produced at the NPR corresponds 
to a feed of 75 to $80 \% \mathrm{~T}_{2}$. ) At this concentration, one thermal column w1ll be sufficient to process the predicted laad of $6 \mathrm{~kg} / \mathrm{yr}$ from the NPR.

\section{TABLE II}

\section{DELETED}

\section{Material of Construction for Crucible}

Tests comparing mild steel and stalnless steel cruclbles showed that the use of $304 \mathrm{~L}$ stainless steel crucibles in the plant should be continued, since stainless evolves significantly less $\mathrm{CO} \mathrm{CO}_{2}$ than does mild steel, as shown in Table III. The expected $\mathrm{CO}+\mathrm{CO}_{2}$ GVR for typical plant operation would be less than the 0.4 observed in Run 16, since the much higher ratio of target to crucible mass in the plant will decrease the relative contribution of $\mathrm{CO}+\mathrm{CO}_{2}$ by the crucible; the empty crucible in Run 22 evolved $\mathrm{CO}+\mathrm{CO}_{2}$ equivalent to $0.32 \mathrm{GVR}$, Implying a contribution of only 0.1 GVR from ceramic in Runs 16, 17, and 21. The data in

\section{TABLE III}

Gases Evolved from Crucibles of Stainless Steel and Carbon Steel

\begin{tabular}{|c|c|c|c|c|c|c|}
\hline Run & $\begin{array}{c}\text { Cructble } \\
\text { Steel }\end{array}$ & Contents & $\begin{array}{l}\text { Temp, } \\
{ }^{\circ} \mathrm{C}\end{array}$ & $\begin{array}{c}\text { Time, } \\
\text { hr }\end{array}$ & $\begin{array}{l}\mathrm{H}_{2}, \\
\text { GVR }\end{array}$ & $\begin{array}{c}\mathrm{CO}+\mathrm{CO}_{2}, \\
\mathrm{GVR}\end{array}$ \\
\hline 15 & $304 E$ & Irr'd. Target & 750 & 11 & 0.66 & 0.80 \\
\hline 21 & $304 \mathrm{~L}$ & Irr'd. Target & 750 & 11 & 1.06 & 0.42 \\
\hline 16 & $304 \mathrm{~L}$ & Irr'd. Target & 850 & 6 & 0.73 & 0.42 \\
\hline 17 & $304 \mathrm{I}$ & Unirr'd. Target & 850 & 4 & 0.70 & 0.40 \\
\hline 22 & $304 \mathrm{~L}$ & Empty & 850 & 4 & $0.74(a)$ & $0.32(a)$ \\
\hline 18 & Carbon & Unirr'd. Target & 850 & 4 & 20.73 & 2.22 \\
\hline 19 & Carbon & Empty & 850 & 4 & $0.51(a)$ & $2.50(a)$ \\
\hline
\end{tabular}

(a) Calculated as though a target were present. 
Table III also indicate that most of the $\mathrm{H}_{2}$ evolved during an extraction comes from the crucible (Runs 22 and 19) and not the target; again, the relative contribution will be diminished in the plant.

\section{Removal of $\mathrm{CO}_{\text {and }} \mathrm{CO}_{2}$}

The $\mathrm{CO}$ and $\mathrm{CO}_{2}$ evolved during the extraction of tritium from the ceramic targets may have detrimental effects in the plant on the performance of the urantum bed decomposer (reduces $\mathrm{H}_{2} \mathrm{O}$, HTO, and $\mathrm{T}_{2} \mathrm{O}$ ) and the palladium diffuser (separates hydrogen isotopes from other components of the process gases). A portion of the $\mathrm{CO}$ and $\mathrm{CO}_{2}$ will be reduced by the urantum, an action which adds to the consumption of uranium and may lead to inactivation by a surface layer of carbon. Decomposition of methane on the paliadium diffuser can decrease its performance sufficlently to require oxidative regeneration; fortunately, methane was not produced when mixtures of $\mathrm{T}_{2}, \mathrm{CO}$, and $\mathrm{CO}_{2}$ were passed through the hot uranium decomposer (Run 13). Because of these uncertainties regarding the effects of $\mathrm{CO}+\mathrm{CO}_{2}$, an additional purification step using a combination of Hopcalite and zeolite beds in serles was developed for the plant in case it should prove necessary to prevent the $\mathrm{CO}+\mathrm{CO}_{2}$ from passing through the uranium decomposer and/or the palladium diffuser. This process is described in the section under Experimental Procedure and is shown in Figure 3 .

Eighty to ninety percent of the $\mathrm{CO}+\mathrm{CO}_{3}$ was separated from the tritium stream by the Hopcalite-zeolite system (Runs 14 and 15), with no tritium lost to the byproduct stream of He and $\mathrm{CO}+\mathrm{CO}_{2}$.

\section{FUTURE WORK}

The extraction process will be conflrmed with additional Irradlated targets from the NPR. These targets, which are more representative of the expected production targets, will have an average ceramic density of $88.6 \%$ of theoretical and an average tritium GVR of 1.4 , compared to $79.3 \%$ and 0.6 for the targets already investigated. The effects of $\mathrm{CO}+\mathrm{CO}_{2}$ on the uranium decomposer and palladium diffuser will be determined and the ability to extract tritium at 750 and $850^{\circ} \mathrm{C}$ w1ll be verified. This evaluation should eliminate the reed for a large-scale demonstration at the Semiworks, and permlt a full-scale extraction test to be conducted at $750^{\circ} \mathrm{C}$ in the plant without equipment modification. 


\section{APPENDIX A}

\section{DETAILED SUMMARY OF DATA OBTAINED}

Table IV summarizes all of the runs made. Tables $V$ through XIV give the detalled composition of the gases evolved at various times during all of the tests with irradiated targets, and during the tests to determine the material of construction for the crucible. 
TABIE IV

Summaxr of Tosts

\begin{tabular}{|c|c|c|c|c|c|c|}
\hline Fun & Furnace Charge & Crucible & $\begin{array}{c}20 m p-T 1 m 0, \\
0 \mathrm{c}-\mathrm{hx} \\
\end{array}$ & $\frac{\mathrm{H}_{2}-}{\mathrm{oc}\left(\mathrm{sin}_{\mathrm{s}}\right)^{-}}$ & al avitat & $\mathrm{H}_{2}$ as $\mathrm{H}_{2} \mathrm{O}$ \\
\hline $1-a$ & $\begin{array}{l}79 \mathrm{~g} \operatorname{tgt}(\text { no } A 1) \\
674 \mathrm{~g} \text { flux }\end{array}$ & Carbon Steel & $\begin{array}{l}800-1 \\
750-\frac{1}{4}\end{array}$ & 710 & 22.6 & 87 \\
\hline $1-b$ & same & Carbon Steel & $780-3$ & 34 & 1.1 & 0 \\
\hline $2-a$ & $1270 \mathrm{~g} / 1 \mathrm{ux}$ (powder) & Carbon Steel. & $600-5$ & 10,400 & 81.3 & 95 \\
\hline $2-b$ & same & Carbon Ste日l & $850-4$ & $<1, \infty$ & $<8.1$ & $\$ 0$ \\
\hline $2-c$ & $\operatorname{san} \theta$ & Carbon Steel & $850-4$ & 213 & 1.7 & 0 \\
\hline $2-d$ & same & Carbon Steel & $1,000-11^{(f)}$ & 276 & 2.2 & 0 \\
\hline $3-2$ & $500 \mathrm{~g} \mathrm{tgt}$ & Carbon Steel & $550-42$ & $\$ 15$ & $<3.1$ & $<97$ \\
\hline $3-b$ & same & Carbon Steel & $850-6$ & 50 & 0.3 & 68 \\
\hline 4 & $500 \mathrm{~g} \mathrm{tgt,1900 \textrm {g }} \mathrm{flux}$ & Carbon Steel & $850-10$ & 893 & 4.5 & 32 \\
\hline 5 & $\begin{array}{l}\text { same as } 4 \text { except tgt } \\
\text { suspended \& no Al }\end{array}$ & Carbon Steel & $850-10$ & 543 & 2.7 & 35 \\
\hline 6 & $500 \mathrm{~g} \mathrm{tgt,} 1070 \mathrm{~g}$ flux & $\begin{array}{l}304 \mathrm{LC} \\
\text { Stalniess Steel }\end{array}$ & $850-10$ & 888 & 4.4 & 54 \\
\hline 7 & $1070 \mathrm{~g} f 1 \mathrm{x}$ & $\begin{array}{l}304 \text { ELC } \\
\text { Stainless Steel }\end{array}$ & $850-7$ & 2,500 & 21.8 & 87 \\
\hline 8 & $\begin{array}{l}410 \mathrm{~g} \text { tgt auspended } \\
1980 \mathrm{~g} \text { flux }\end{array}$ & Carbon Steel & $850-20$ & 1,670 & 9.0 & 83 \\
\hline 9 & $4 \log \operatorname{tg} t$ & Carbon Steol & $850-21$ & 405 & 2,2 & 67 \\
\hline 10 & $2230 \mathrm{~g}$ flux & Carbon Steel & $850-11$ & 2,250 & 7.0 & 55 \\
\hline 11 & $\begin{array}{l}410 \mathrm{~g} \text { tg } \mathrm{t}^{(h)} \text { guspended } \\
1980 \mathrm{~g} \text { pretreated flux }\end{array}$ & Carbon Steel & $850-20$ & 275 & 1.5 & 53 \\
\hline 12 & $\begin{array}{l}410 \mathrm{~g} \text { tgt suapended } \\
1980 \mathrm{~g} \text { pretreated flux }\end{array}$ & Carbon 3teel & $850-<4$ & 242 & 2.4 & $p^{(1)}$ \\
\hline 13 & $4 \mathrm{log} t g t$ & $\begin{array}{l}304 \mathrm{~L} \\
\text { Stalnless Steel }\end{array}$ & $900-24$ & 266 & 3.5 & $p(1)$ \\
\hline 14 & $40 g \mathrm{tg} t$ & $\begin{array}{l}304 \mathrm{~L} \\
\text { Stainlese Steel }\end{array}$ & $850-11$ & 445 & 2.4 & (1) \\
\hline 15 & $4 \log$ tgt & $\begin{array}{l}304 \mathrm{~L} \\
\text { Stalnless Steel }\end{array}$ & $750-11$ & 122 & 0.7 & $?^{(j)}$ \\
\hline 16 & $4 \log t g t$ & $\begin{array}{l}304 \mathrm{~L} \\
\text { Stainless Steel }\end{array}$ & $850-6$ & 134 & 0.7 & 35 \\
\hline 17 & $500 \mathrm{~g} \mathrm{tgt}$ & $\begin{array}{l}304 \mathrm{~L} \\
\text { Stainless steel }\end{array}$ & $850-4$ & 139 & 0.7 & 46 \\
\hline 28 & $500 \mathrm{~g} \mathrm{tgt}$ & Carbon Stael & $850-4$ & 1.46 & 0.7 & 29 \\
\hline 19 & Carbon Steel Crucible & Carbon Steel & $850-4$ & 94 & $0.5^{(1)}$ & 30 \\
\hline 20 & Fes1due from Run 15 & $\begin{array}{l}\text { 304L, } \\
\text { Stainless Steel }\end{array}$ & 850.6 & $254^{(m)}$ & 1.4 & $p(1)$ \\
\hline 21 & $410 \mathrm{~g}$ tgt & Stalnless Steel & $750-11$ & 196 & 1.1 & 35 \\
\hline 22 & 304L Crualble & $\begin{array}{l}\text { 304L, } \\
\text { Staínless Steel }\end{array}$ & $850-4$ & 136 & $0.7^{\prime} 1^{\prime}$ & 16 \\
\hline 23 & Rea1due from Run 2l & $\begin{array}{l}304 \mathrm{~L} \\
\text { Stainless }\end{array}$ & $850-6$ & $1210^{(n)}$ & 6.0 & $r^{(1)}$ \\
\hline $\begin{array}{l}\text { (b) } \\
\text { (o) }\end{array}$ & $\begin{array}{l}\text { ove - ratio, roluge of ga } \\
\text { If flux 1s present but no } \\
\text { to oharge welght ratio 1a } \\
\text { as if tgt were present. } \\
\text { Some hellum in target prio } \\
\text { Irradlated targete uged in } \\
20 \text {, and } 21 \text {. }\end{array}$ & $\begin{array}{l}\text { ls at sTP to volune } \\
\text { target material, a } \\
\text { assumed and oVR 18 } \\
\text { or to imradiation. } \\
\text { a Funs } 8,9,12,12\end{array}$ & $\begin{array}{l}\text { of target. } \\
4 / 1 \text { plux } \\
\text { expressed } \\
\text { through } 16 \text {, }\end{array}$ & & & \\
\hline
\end{tabular}




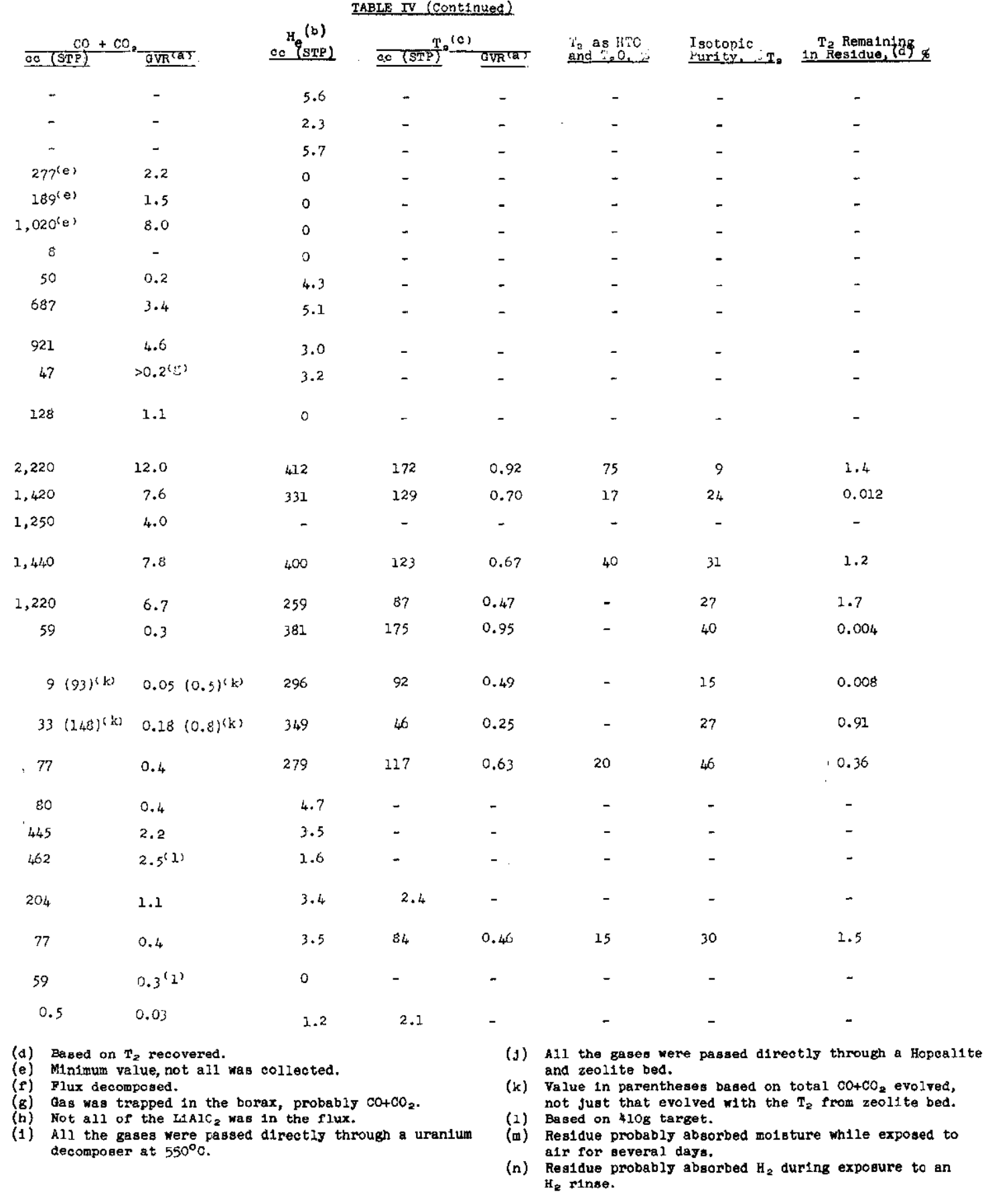


TABLE V

Fun 8: Gases Evolved from Irradiated Target in Flux at $850^{\circ} \mathrm{C}$ for 20 Hours - Carbon Steel Cruc1ble.

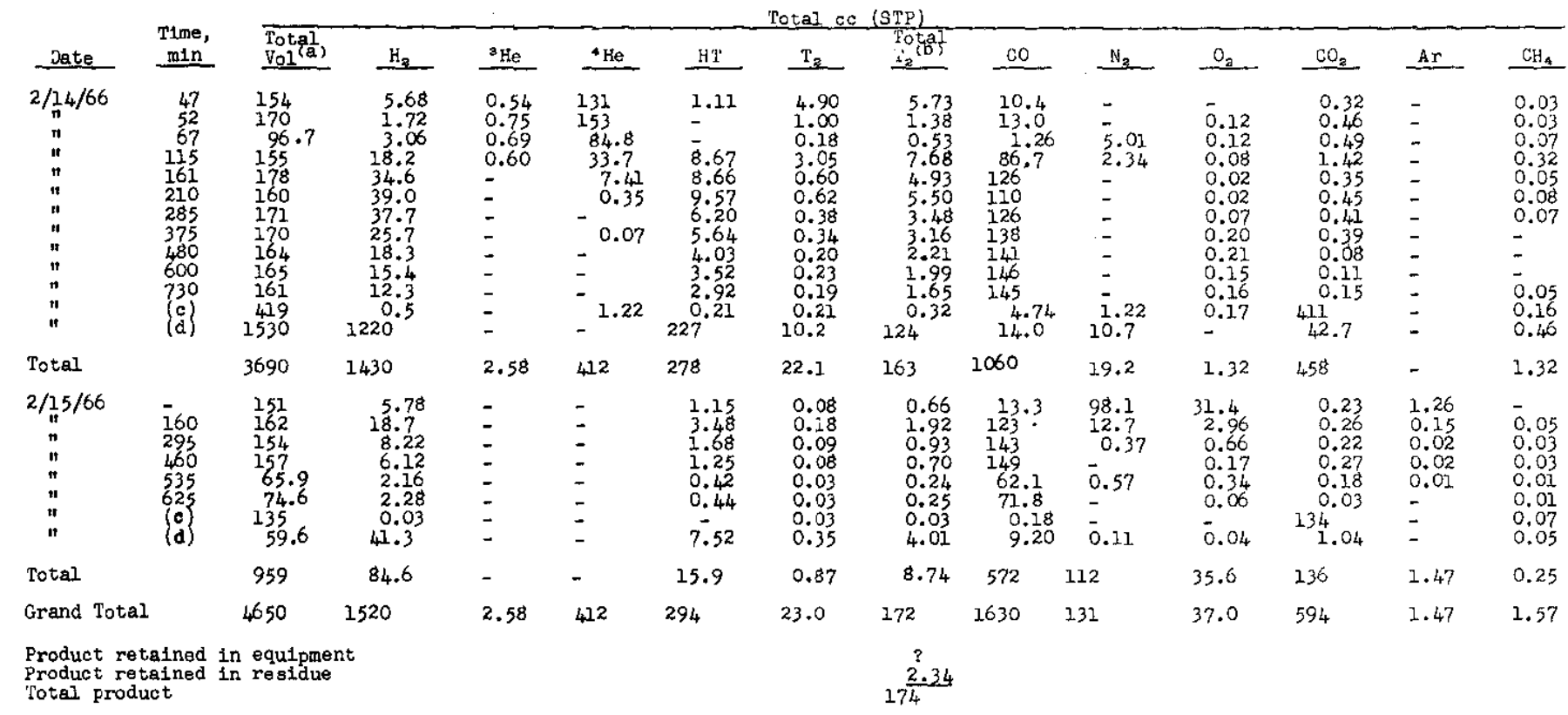

(a) Column 9 not included.

(b) Includes $1 / 2$ the ${ }^{3} \mathrm{He}$ found.

(c) aases evolved froul cold trap while thawing.

(d) Gases evolved from heating cold trap and passing gases through a uranium decomposer at $550^{\circ} \mathrm{C}$. 
TABLE VI

Run 9: Gases Evolved from Irradiated Target at $850^{\circ} \mathrm{C}$ for 21 Hours Carbon Steel Cruc1ble

\begin{tabular}{|c|c|c|c|c|c|c|c|c|c|c|c|c|c|c|}
\hline \multirow[b]{2}{*}{ Late } & \multirow[b]{2}{*}{$\begin{array}{l}\text { Time, } \\
\min \\
\end{array}$} & \multicolumn{13}{|c|}{ Total Co (STP) } \\
\hline & & $\begin{array}{l}\text { 'lotal } \\
\text { Vol(a) }\end{array}$ & $\mathrm{H}_{3}$ & ${ }^{3} \mathrm{He}$ & ${ }^{4} \mathrm{He}$ & HT & $\mathrm{T}_{2}$ & $\begin{array}{l}\text { Total } \\
T_{a}(b) \\
\end{array}$ & co & $\mathrm{N}_{2}$ & $\mathrm{CO}_{\mathrm{g}}$ & Ar & $\mathrm{CH}_{4}$ & $\mathrm{O}_{2}$ \\
\hline $\begin{array}{l}2 / 17 / 66 \\
" 1 \\
" 1 \\
" 1 \\
" 1 \\
" 1 \\
" 1 \\
" 1 \\
" 1 \\
" 1 \\
" 1 \\
" 1\end{array}$ & $\begin{array}{r}29 \\
35 \\
49 \\
60 \\
74 \\
81 \\
107 \\
165 \\
285 \\
420 \\
540 \\
630 \\
720 \\
\text { (c) } \\
\text { d }\end{array}$ & $\begin{array}{c}169 \\
155 \\
159 \\
163 \\
168 \\
164 \\
169 \\
177 \\
167 \\
112 \\
70.6 \\
42.6 \\
38.9 \\
94.2 \\
326.2\end{array}$ & $\begin{array}{r}19.1 \\
6.41 \\
15.1 \\
4.72 \\
3.07 \\
3.43 \\
4.07 \\
4.69 \\
5.54 \\
4.47 \\
3.21 \\
2.05 \\
2.10 \\
0.01 \\
245\end{array}$ & $\begin{array}{l}0.47 \\
0.93 \\
0.57 \\
- \\
0.03 \\
0.02 \\
= \\
= \\
0.02 \\
= \\
=\end{array}$ & $\begin{array}{c}128 \\
127 \\
50.5 \\
6.03 \\
5.21 \\
5.16 \\
3.30 \\
1.58 \\
1.12 \\
0.66 \\
0.39 \\
0.20 \\
0.18 \\
0.39\end{array}$ & $\begin{array}{c}1.35 \\
5.62 \\
15.6 \\
15.7 \\
11.0 \\
8.28 \\
7.12 \\
5.52 \\
4.61 \\
3.07 \\
2.15 \\
1.18 \\
1.15 \\
0.01 \\
39.7\end{array}$ & $\begin{array}{c}2.75 \\
1.49 \\
5.06 \\
15.7 \\
10.7 \\
5.22 \\
3.18 \\
1.75 \\
1.02 \\
0.61 \\
0.34 \\
0.19 \\
0.16 \\
0.01 \\
1.73\end{array}$ & $\begin{array}{r}3.67 \\
4.76 \\
13.2 \\
23.5 \\
16.2 \\
9.38 \\
6.75 \\
4.51 \\
3.32 \\
2.15 \\
1.44 \\
0.79 \\
0.74 \\
0.02 \\
21.6\end{array}$ & $\begin{array}{c}3.06 \\
2.93 \\
56.9 \\
110 \\
1134 \\
126 \\
142 \\
138 \\
154 \\
153 \\
60.4 \\
35.5 \\
34.0 \\
=\end{array}$ & $\begin{array}{c}13.0 \\
10.2 \\
15.2 \\
9.64 \\
2.75 \\
15.3 \\
8.04 \\
24.7 \\
-.7 \\
3.97 \\
3.44 \\
1.33 \\
0.44 \\
5.98\end{array}$ & $\begin{array}{c}0.22 \\
0.39 \\
0.57 \\
1.24 \\
1.47 \\
0.86 \\
0.71 \\
0.18 \\
0.22 \\
0.04 \\
0.03 \\
0.01 \\
93.6 \\
32.9\end{array}$ & $\begin{array}{l}0.35 \\
0.26 \\
0.08 \\
= \\
= \\
= \\
= \\
0.01 \\
= \\
\overline{0} \\
0.07\end{array}$ & $\begin{array}{l}0.41 \\
0.08 \\
0.10 \\
0.03 \\
0.03 \\
0.03 \\
0.07 \\
0.05 \\
0.03 \\
0.02 \\
0.01 \\
0.01 \\
0.01 \\
0.08 \\
-\end{array}$ & $\begin{array}{l}z \\
z \\
- \\
0.05 \\
0.08 \\
0.02 \\
0.14 \\
0.03 \\
0.04 \\
0.05 \\
0.06 \\
0.06 \\
0.06 \\
0.56\end{array}$ \\
\hline 'i'otal & & 2180 & 323 & 2.04 & 330 & 122 & 49.9 & 112 & 2100 & 114 & 132 & 0.77 & 0.96 & 1.15 \\
\hline $\begin{array}{c}2 / 18 / 66 \\
" 1 \\
" 1 \\
"\end{array}$ & $\begin{array}{l}255 \\
450 \\
630 \\
780 \\
(\mathrm{e})\end{array}$ & $\begin{array}{l}59.5 \\
59.0 \\
48.6 \\
36.4 \\
10.0\end{array}$ & $\begin{array}{l}4.22 \\
2.97 \\
2.44 \\
1.95 \\
5.61\end{array}$ & $\begin{array}{l}\bar{z} \\
\bar{z}\end{array}$ & $\begin{array}{l}0.19 \\
0.22 \\
0.16 \\
0.11 \\
-\end{array}$ & $\begin{array}{l}2.41 \\
1.60 \\
1.28 \\
0.93 \\
1.09\end{array}$ & $\begin{array}{l}0.30 \\
0.19 \\
0.15 \\
0.09 \\
0.05\end{array}$ & $\begin{array}{l}1.50 \\
0.99 \\
0.79 \\
0.55 \\
0.59\end{array}$ & $\begin{array}{l}52.0 \\
50.9 \\
41.5 \\
30.6 \\
-\end{array}$ & $\begin{array}{l}0.21 \\
3.07 \\
2.99 \\
2.69 \\
0.23\end{array}$ & $\begin{array}{l}0.03 \\
\overline{0} .01 \\
\overline{2} .99\end{array}$ & $\begin{array}{l}\overline{-} \\
\overline{-} \\
0.01\end{array}$ & $\begin{array}{l}0.13 \\
0.02 \\
0.01 \\
0.01 \\
-\end{array}$ & $\begin{array}{l}0.04 \\
0.04 \\
0.08 \\
0.05 \\
0.02\end{array}$ \\
\hline l'otal & & 214 & 17.2 & - & 0.68 & 7.31 & 0.78 & 4.42 & 275 & 9.19 & 3.03 & 0.01 & 0.17 & 0.23 \\
\hline Crand tot & & 2390 & 340 & 2.04 & 331 & 129 & 50.7 & 116 & 1280 & 123 & 135 & 0.78 & 1.13 & 1.38 \\
\hline
\end{tabular}

(a) Coiumn 9 not included.

(b) Includes $1 / 2$ the ${ }^{3} \mathrm{He}$ found.

c) Gases evolved from cold trap while thawing.

(d) Gases evolved from heating cold trap and passing gases throughi a uranium bed decomposer at $550^{\circ} \mathrm{C}$

(e) Combination of (c) and (d). 
TABIE VII

Run 11: Gaes Evolved from Irradiated Target in Pre-Treated Flux* at $850^{\circ} \mathrm{C}$ for 20 Hours - Carbon Stee 1 Cructble

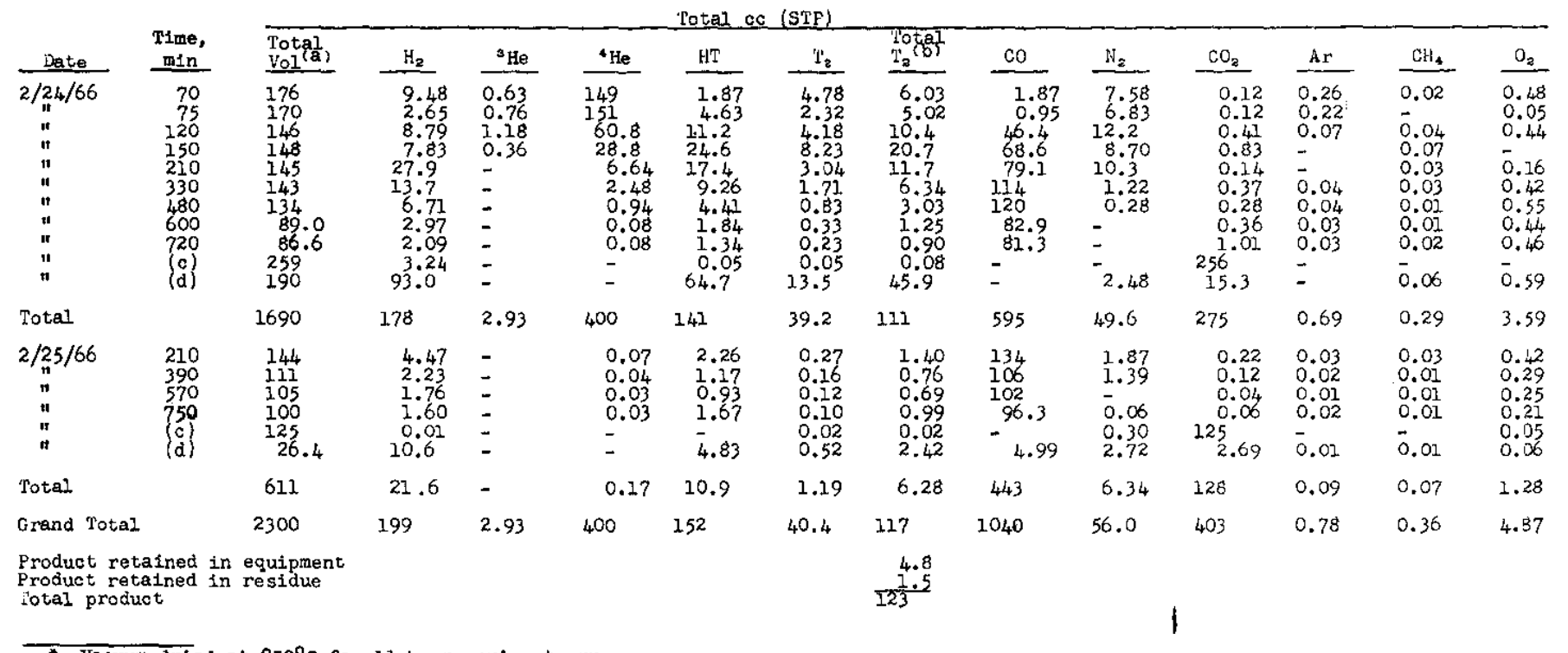

arled at $850^{\circ} \mathrm{C}$ for 11 hours prior to mun.

(a) Column 9 not included.

(b) Inaludes $1 / 2$ the He found.

cases evolved from cold trap whlle thawing.

d) Gases evolved from heating cold trap and paseing gases through a urantum bed decomposer at $550^{\circ} \mathrm{C}$. 
TABLE VIII

Run 12: Gases Evolved from Irradiated Target in Pre-Treated* Flux at $850^{\circ} \mathrm{C}$ for 24 Hours - Carbon Steel Cruolble

\begin{tabular}{|c|c|c|c|c|c|c|c|c|c|c|c|c|c|c|}
\hline \multirow[b]{2}{*}{ Date } & \multirow[b]{2}{*}{$\begin{array}{l}\text { Time, } \\
\text { min } \\
\end{array}$} & \multicolumn{13}{|c|}{ Total cc (STP) } \\
\hline & & $\begin{array}{l}\text { Total } \\
\text { vol(a) }\end{array}$ & $\underline{H_{2}}$ & s sie & \&He & $\mathrm{HT}^{\mathrm{T}}$ & $\mathrm{T}_{3}$ & $\begin{array}{l}\text { Totat } \\
T_{3}(b) \\
\end{array}$ & co & $\mathrm{N}_{\mathrm{a}}$ & $\mathrm{CO}_{\mathrm{a}}$ & Ar & $\mathrm{CH}_{4}$ & $\underline{O_{3}}$ \\
\hline $\begin{array}{l}3 / 7 / 66 \\
" 1 \\
" 1 \\
" 1 \\
" 1\end{array}$ & $\begin{array}{l}136 \\
285 \\
290 \\
440 \\
620 \\
800\end{array}$ & $\begin{array}{l}547 \\
135 \\
157 \\
156 \\
145 \\
123\end{array}$ & $\begin{array}{c}91.7 \\
21.2 \\
20.6 \\
15.6 \\
9.77 \\
6.47\end{array}$ & $\begin{array}{l}2.19 \\
0.01 \\
= \\
=\end{array}$ & $\begin{array}{r}249 \\
8.55 \\
1.38 \\
0.45 \\
0.03 \\
-\end{array}$ & $\begin{array}{c}51.0 \\
20.2 \\
16.0 \\
10.0 \\
5.69 \\
3.58\end{array}$ & $\begin{array}{r}13.1 \\
4.24 \\
2.97 \\
1.58 \\
0.78 \\
0.47\end{array}$ & $\begin{array}{c}39.7 \\
14.3 \\
11.0 \\
6.60 \\
3.63 \\
2.26\end{array}$ & $\begin{array}{l}122 \\
76.4 \\
110.4 \\
122 \\
122 \\
107\end{array}$ & $\begin{array}{l}11.0 \\
\vdots \\
\vdots \\
\vdots\end{array}$ & $\begin{array}{l}4.77 \\
3.98 \\
6.40 \\
6.44 \\
6.16 \\
5.50\end{array}$ & $\begin{array}{l}1.70 \\
0.01 \\
0.03 \\
0.01 \\
-\end{array}$ & $\begin{array}{l}0.44 \\
0.03 \\
0.03 \\
0.03 \\
0.03 \\
0.02\end{array}$ & $\begin{array}{l}0.33 \\
0.01 \\
0.02 \\
0.11 \\
0.07 \\
0.06\end{array}$ \\
\hline Potal & & 1263 & 165 & 2,20 & 259 & 206 & 23.1 & 77.5 & 659 & 11.0 & 33.3 & 1.75 & 0.58 & 0.60 \\
\hline $\begin{array}{c}3 / 8 / 66 \\
" 1 \\
" 1\end{array}$ & $\begin{array}{l}210 \\
360 \\
570 \\
870\end{array}$ & $\begin{array}{l}129 \\
118 \\
142 \\
175\end{array}$ & $\begin{array}{l}7.99 \\
3.22 \\
3.47 \\
4.28\end{array}$ & 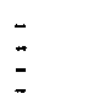 & $=$ & $\begin{array}{l}3.67 \\
1.64 \\
1.63 \\
1.85\end{array}$ & $\begin{array}{l}0.37 \\
0.18 \\
0.19 \\
0.21\end{array}$ & $\begin{array}{l}2.21 \\
0.95 \\
1.01 \\
1.13\end{array}$ & $\begin{array}{l}108 \\
104 \\
126 \\
156\end{array}$ & $=0.53$ & $\begin{array}{l}8.20 \\
8.84 \\
10.8 \\
12.3\end{array}$ & $\begin{array}{l}0.01 \\
\vec{z} \\
=\end{array}$ & $\begin{array}{l}0.01 \\
0.02 \\
0.01 \\
0.02\end{array}$ & $\begin{array}{l}0.01 \\
0.12 \\
0.03 \\
0.07\end{array}$ \\
\hline Total & & 564 & 19.0 & - & 259 & 8.70 & 0.95 & 5.30 & 494 & 0.53 & 40.1 & 0.01 & 0.05 & 0.23 \\
\hline Grand Total & & 1830 & 184 & 2.20 & & 115 & 24.1 & 82.8 & 1150 & 11.5 & 73.4 & 1.76 & 0.63 & 0.83 \\
\hline $\begin{array}{l}\text { Product re } \\
\text { Product re } \\
\text { Total prod }\end{array}$ & ned & $\begin{array}{l}\text { quipme } \\
\text { esidue }\end{array}$ & & & & & & $\begin{array}{r}3.9 \\
1.5 \\
88.2\end{array}$ & & & & & & \\
\hline
\end{tabular}

* Vacuum dried at $850^{\circ} \mathrm{C}$ for 11 hours prior to run.

(a) Column 9 not Included; alI of the gases passed directly through uranium bed decomposer

(b) at $550^{\circ} \mathrm{C}$ during the man. 
TABLE IX

Fun 13: Gases Evolved from Irradiated Target at $900^{\circ} \mathrm{C}$ for 24 Hours - 304L Sta1nless Steel Cmuc1ble

\begin{tabular}{|c|c|c|c|c|c|c|c|c|c|c|c|c|c|c|}
\hline \multirow[b]{2}{*}{ Date } & \multirow[b]{2}{*}{$\begin{array}{l}\text { Time, } \\
\text { min } \\
\end{array}$} & \multicolumn{13}{|c|}{ rotal $C E$ (STP) } \\
\hline & & $\begin{array}{l}\text { Total } \\
\text { Vol }(\mathrm{a})\end{array}$ & $\mathrm{H}_{2}$ & ${ }^{3} \mathrm{He}$ & s He & $\mathrm{H} T$ & $T_{3}$ & Total & $\mathrm{CO}$ & $\mathrm{N}_{2}$ & $\mathrm{CO}_{2}$ & Ar & $\mathrm{CH}_{4}$ & $\mathrm{O}_{2}$ \\
\hline $\begin{array}{c}3 / 120 / 66 \\
1 "\end{array}$ & $\begin{array}{r}95 \\
230 \\
800\end{array}$ & $\begin{array}{l}689 \\
121 \\
55.0\end{array}$ & $\begin{array}{l}118 \\
23.9 \\
23.6\end{array}$ & $\begin{array}{l}2.96 \\
0.02\end{array}$ & $\begin{array}{l}361 \\
16.3 \\
2.33\end{array}$ & $\begin{array}{c}110 \\
37.9 \\
18.1\end{array}$ & $\begin{array}{r}45.0 \\
16.2 \\
4.16\end{array}$ & $\begin{array}{c}102 \\
35.1 \\
13.2\end{array}$ & $\begin{array}{r}24.4 \\
24.5 \\
5.12\end{array}$ & $\begin{array}{r}23.2 \\
1.38 \\
1.38\end{array}$ & $\begin{array}{l}3.31 \\
0.92 \\
0.11\end{array}$ & $\begin{array}{l}0.75 \\
0.01 \\
0.04\end{array}$ & $\begin{array}{l}0.48 \\
0.02 \\
0.03\end{array}$ & $\begin{array}{l}0.20 \\
0.01 \\
0.11\end{array}$ \\
\hline Total & & 865 & 266 & 2.98 & 380 & 166 & 65.4 & 150 & 54.0 & 26.0 & 4.34 & 0.80 & 0.53 & 0.32 \\
\hline $3 / \frac{11}{n} 1 / 66$ & $\begin{array}{l}300 \\
870\end{array}$ & 11.1 & $\begin{array}{l}5.79 \\
7.20\end{array}$ & 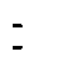 & $\begin{array}{l}0.18 \\
0.34\end{array}$ & $\begin{array}{l}3.82 \\
4.04\end{array}$ & $\begin{array}{l}0.55 \\
0.50\end{array}$ & $\begin{array}{l}2.46 \\
2.52\end{array}$ & $\begin{array}{l}0.27 \\
0.20\end{array}$ & $\begin{array}{l}0.34 \\
0.23\end{array}$ & $\begin{array}{l}0.02 \\
0.02\end{array}$ & $\begin{array}{l}0.03 \\
0.02\end{array}$ & $\begin{array}{l}0.05 \\
0.01\end{array}$ & $\begin{array}{l}0.05 \\
0.04\end{array}$ \\
\hline Total & & 23.7 & 23.0 & - & 0.52 & 7,86 & 1.05 & 4.98 & 0.47 & 0.57 & 0.04 & 0.05 & 0.06 & 0.09 \\
\hline Grand To & & 889 & 179 & 2.98 & 381 & 274 & 66.5 & 155 & 54.5 & 26.6 & 4.38 & 0.85 & 0.59 & 0.42 \\
\hline
\end{tabular}

Product retained in equipment

Product retained in residue

Total product

20.0
0.007
275

(a) column 9 not 1ncluded; all of the gases passed directly through uranium bed decomposer at

(b) Inoludes $1 / 2$ the ${ }^{3} \mathrm{He}$ found. 
TABLE X

Run 14: aases Evolved from Irradiated Target at $850^{\circ} \mathrm{C}$

for 11 Hours - 304L Stalnless Steel Crucible

\begin{tabular}{|c|c|c|c|c|c|c|c|c|c|c|c|c|c|c|}
\hline \multirow[b]{2}{*}{ Late } & \multirow[b]{2}{*}{$\begin{array}{l}\text { Time, } \\
\text { min } \\
\end{array}$} & \multicolumn{13}{|c|}{ Lotal ac (STP) } \\
\hline & & $\begin{array}{l}\text { Potal } \\
\text { Vol }\end{array}$ & $\mathrm{H}_{2}$ & He & $\bullet \mathrm{He}$ & $\mathrm{HI}$ & $\mathrm{T}_{\mathrm{a}}$ & $\begin{array}{l}\text { Potgis } \\
\mathrm{T}_{3}(\mathrm{~s}) \\
\end{array}$ & $\mathrm{CO}$ & $\mathrm{N}_{2}$ & $\underline{\mathrm{CO}_{2}}$ & Ar & $\mathrm{CH}_{4}$ & $\mathrm{O}_{2}$ \\
\hline $\begin{array}{c}\text { 3/22/66 } \\
n " \\
"\end{array}$ & $\begin{array}{r}62 \\
72 \\
370 \\
760\end{array}$ & $\begin{array}{l}175 \\
177 \\
153 \\
38.6\end{array}$ & $\begin{array}{l}0.02 \\
0.06 \\
0.06\end{array}$ & $\begin{array}{l}0.70 \\
1.89 \\
0.70 \\
0.03\end{array}$ & $\begin{array}{l}111 \\
241 \\
42.3 \\
1.41\end{array}$ & $\begin{array}{l}\overline{-} \\
\bar{z}\end{array}$ & $\begin{array}{l}\bar{z} \\
\bar{z}\end{array}$ & $\begin{array}{l}0.35 \\
0.94 \\
0.35 \\
0.01\end{array}$ & $\begin{array}{l}\bar{z} \\
\bar{z}\end{array}$ & $\begin{array}{c}14.2 \\
12.5 \\
4.04 \\
0.90\end{array}$ & $\begin{array}{l}7.17 \\
12.3 \\
51.2 \\
12.8\end{array}$ & $\begin{array}{l}0.35 \\
0.30 \\
0.02 \\
-\end{array}$ & $\begin{array}{l}0.28 \\
0.23 \\
0.08 \\
0.02\end{array}$ & $\begin{array}{l}41.3 \\
8.48 \\
54.1 \\
23.4\end{array}$ \\
\hline l'otal & & 544 & 0.14 & 3.32 & 296 & - & - & 1.65 & - & 31.6 & 83.5 & 0.67 & 0.61 & 127 \\
\hline $\begin{array}{l}3 / 22 / 66 \\
3 / 23 / 66\end{array}$ & $\left(\begin{array}{l}c \\
c\end{array}\right)$ & $\begin{array}{l}515 \\
124\end{array}$ & $\begin{array}{c}363 \\
14.2\end{array}$ & $=$ & $=$ & ${ }_{4.53}^{130}$ & $\begin{array}{r}12.2 \\
0.43\end{array}$ & $\begin{array}{r}77.1 \\
2.69\end{array}$ & $\begin{array}{l}5.56 \\
0.43\end{array}$ & 102.03 & $\begin{array}{l}2.73 \\
0.41\end{array}$ & $\overline{1.64}$ & $\begin{array}{l}0.05 \\
0.01\end{array}$ & $\begin{array}{l}0.10 \\
0.04\end{array}$ \\
\hline Potal & & 639 & 377 & - & - & 135 & 12.6 & 79.8 & 5.99 & 103 & 3.14 & 1.64 & 0.06 & 0.14 \\
\hline Grand Tota & & 1180 & 377 & 3.32 & 296 & 135 & 12.6 & 81.5 & 5.99 & 135 & 86.6 & 2.31 & 0.67 & 127 \\
\hline \multicolumn{8}{|c|}{$\begin{array}{l}\text { Product retained in equipment } \\
\text { Product retained in residue } \\
\text { Total product }\end{array}$} & $\begin{array}{l}10.7 \\
\frac{0.007}{92.2}\end{array}$ & & & & & & \\
\hline
\end{tabular}

(a) Column 9 not 1ncluded; all of the gases passed directly through Hopealite and zeollte deds.

(b) Inoludes $1 / 2$ the ${ }^{3} \mathrm{He}$ found. 


\section{TABLE XI}

Fun 15: Gases Evolved from Irradiated Target at $750^{\circ} \mathrm{C}$ for 11 Hours - 304L Sta1nless Stee1 Crucible

\begin{tabular}{|c|c|c|c|c|c|c|c|c|c|c|c|c|c|c|}
\hline \multirow[b]{2}{*}{ Date } & \multirow[b]{2}{*}{$\begin{array}{r}\text { Time, } \\
\text { m1ri } \\
\end{array}$} & \multicolumn{13}{|c|}{ Total $\mathrm{Cc}$ (STP) } \\
\hline & & $\begin{array}{l}\text { Total } \\
\text { Vor(a) }\end{array}$ & $\mathrm{H}_{2}$ & ${ }^{3} \mathrm{He}$ & 4 He & HT & $\mathrm{T}_{\mathrm{a}}$ & 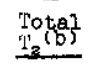 & $\mathrm{CO}$ & $\mathrm{N}_{2}$ & $\underline{\mathrm{CO}_{3}}$ & Ar & $\mathrm{CH}_{4}$ & $\mathrm{O}_{2}$. \\
\hline $\begin{array}{c}3 / 28 / 66 \\
n \\
n \\
n\end{array}$ & $\begin{array}{r}67 \\
76 \\
280 \\
775\end{array}$ & $\begin{array}{c}175 \\
179 \\
129 \\
62.1\end{array}$ & $\begin{array}{l}- \\
\overline{0} .03 \\
0.05\end{array}$ & $\begin{array}{l}1.01 \\
2.09 \\
1.10 \\
0.04\end{array}$ & $\begin{array}{r}142 \\
156 \\
49.3 \\
1.53\end{array}$ & $\bar{z}$ & $\begin{array}{l}\overline{-} \\
0.01\end{array}$ & $\begin{array}{l}0.50 \\
1.04 \\
0.55 \\
0.02\end{array}$ & $=$ & $\begin{array}{l}14.8 \\
9.56 \\
13.2 \\
15.6\end{array}$ & $\begin{array}{l}10.1 \\
10.7 \\
58.1 \\
36.5\end{array}$ & $\begin{array}{l}0.35 \\
0.32 \\
0.24 \\
0.20\end{array}$ & $\begin{array}{l}0.26 \\
0.25 \\
0.09 \\
0.02\end{array}$ & $\begin{array}{l}5.93 \\
0.11 \\
7.17 \\
8.10\end{array}$ \\
\hline Total & & 545 & 0.08 & 4.24 & 349 & - & 0.01 & 2.11 & - & 53.2 & 21.5 & 1.01 & 0.62 & 21.3 \\
\hline $\begin{array}{l}3 / 28 / 66 \\
3 / 29 / 66\end{array}$ & $\left\{\begin{array}{l}c \\
c\end{array}\right\}$ & $\begin{array}{c}153 \\
76.6\end{array}$ & $\begin{array}{l}78.7 \\
20.2\end{array}$ & $=$ & $=$ & $\begin{array}{l}35.4 \\
10.7\end{array}$ & $\begin{array}{l}4.49 \\
3.39\end{array}$ & $\begin{array}{c}22.2 \\
6.73\end{array}$ & $\overline{9} .80$ & $\begin{array}{l}12.4 \\
32.6\end{array}$ & $\begin{array}{c}21.4 \\
1.31\end{array}$ & $\begin{array}{l}0.10 \\
0.60\end{array}$ & $\begin{array}{l}0.03 \\
0.02\end{array}$ & $\begin{array}{l}0.15 \\
0.04\end{array}$ \\
\hline Total & & 230 & 98.9 & - & -310 & 46.1 & 5.88 & 28.9 & 9.80 & 45.0 & 22.7 & 0.70 & 0.05 & 0.19 \\
\hline Grand Total & & 775 & 99.0 & 4.24 & 349 & 46.1 & 5.89 & 31.0 & 9.80 & 98.2 & 138 & 1.71 & 0.67 & 21.5 \\
\hline $\begin{array}{l}\text { Product ret } \\
\text { Product ret } \\
\text { Total produ }\end{array}$ & ned & $\begin{array}{l}\text { ufpme } \\
\text { siadue }\end{array}$ & & & & & & $\begin{array}{l}25.0 \\
\frac{0.42}{40.4}\end{array}$ & & & & & & \\
\hline
\end{tabular}

(a) Column 9 not included; all of the gases passed alrectly through Hopcalite and zeoll te beds.

(b) Includes $1 / 2$ the sHe found.
(c) Gases evolved after heating zeoll te bed to $500^{\circ} \mathrm{C}$. 


\section{TABLE XII}

Run 16: Gases Evolved from Irradiated Target at $850^{\circ} \mathrm{C}$ for 6 Hours $=304 \mathrm{E}$ Stainless Steel Cruc1ble

\begin{tabular}{|c|c|c|c|c|c|c|c|c|c|c|c|c|c|c|}
\hline \multirow[b]{2}{*}{ vate } & \multirow{2}{*}{$\begin{array}{l}\text { Time, } \\
\text { min }\end{array}$} & \multicolumn{13}{|c|}{ Total ac (STP) } \\
\hline & & $\begin{array}{l}\text { Tot? } \\
\text { vol }\end{array}$ & $\mathrm{H}_{2}$ & ${ }^{3} \mathrm{He}$ & $4 \mathrm{He}$ & $\mathrm{HT}$ & $T_{B}$ & 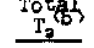 & $\mathrm{co}$ & $\mathrm{N}_{3}$ & Ar & $\mathrm{CH}_{4}$ & $0_{8}$ & $\mathrm{CO}_{\mathrm{a}}$ \\
\hline $\begin{array}{c}3 / 30 / 66 \\
11\end{array}$ & $\begin{array}{r}68 \\
90 \\
460\end{array}$ & $\begin{array}{l}179 \\
185 \\
152\end{array}$ & $\begin{array}{l}18.0 \\
22.5 \\
16.1\end{array}$ & $\begin{array}{l}0.77 \\
2.13 \\
0.32\end{array}$ & $\begin{array}{l}137 \\
110 \\
32.2\end{array}$ & $\begin{array}{c}2.63 \\
24.4 \\
34.0\end{array}$ & $\begin{array}{l}1.25 \\
\frac{13.1}{24.4}\end{array}$ & $\begin{array}{l}2.95 \\
26.4 \\
41.5\end{array}$ & $\begin{array}{r}5.02 \\
4.30 \\
43.0\end{array}$ & $\begin{array}{r}13.6 \\
8.40 \\
0.23\end{array}$ & $\begin{array}{l}0.41 \\
0.19\end{array}$ & $\begin{array}{l}0.11 \\
0.09 \\
0.06\end{array}$ & $\begin{array}{l}0.27 \\
0.07 \\
0.05\end{array}$ & $\begin{array}{l}0.13 \\
0.13 \\
0.48\end{array}$ \\
\hline Fotal & & 515 & 56.6 & 3.22 & 279 & 61.0 & 38.8 & 70.9 & 52.3 & 22.2 & 0.60 & 0.26 & 0.39 & 0.72 \\
\hline $3 / 30 / 66$ & $\left(\begin{array}{l}c \\
d\end{array}\right)$ & $\begin{array}{l}13.0 \\
67.9\end{array}$ & $\begin{array}{c}0.01 \\
39.7\end{array}$ & - & - & $i_{4.3}$ & -1.94 & -9.10 & $\begin{array}{l}0.21 \\
3.34\end{array}$ & $\begin{array}{l}0.16 \\
0.24\end{array}$ & 0.02 & $\begin{array}{l}0.01 \\
0.06\end{array}$ & $\begin{array}{l}0.06 \\
0.03\end{array}$ & $\begin{array}{c}32.5 \\
8.26\end{array}$ \\
\hline iotal & & 80.9 & 39.7 & - & - & 14.3 & 1.94 & 9.10 & 3.55 & 0.40 & 0.02 & 0.07 & 0.09 & 20.8 \\
\hline Grand lot & & 596 & 96.3 & 3.22 & 279 & 75.3 & 40.7 & 80.0 & 55.9 & 22.7 & 0.62 & 0.33 & 0.48 & 21.5 \\
\hline \multicolumn{8}{|c|}{ Product retained by equipment } & 36.7 & & & & & & \\
\hline \multicolumn{8}{|c|}{ Product retained in residue } & 0.42 & & & & & & \\
\hline \multicolumn{8}{|c|}{ 'otal product } & 217 & & & & & & \\
\hline
\end{tabular}

(a) Column 9 not included.

Includes $1 / 2$ the ${ }^{3}$ He found.

evolved from oold trap due to thawing.

(d) aases evolved from heat1ng cold trap and passing gases through a uranium decomposer at $550^{\circ} \mathrm{Cl}$ 
TABLE XIII

Funs 17, 18, 19, and 22: Gases Evolved from Carbon and Sta1nless Steel Cruclbles at $850^{\circ} \mathrm{C}$

Total ce (STP)

\begin{tabular}{|c|c|c|c|c|c|c|c|c|c|c|c|c|c|c|c|c|}
\hline Run & Date & $\begin{array}{l}\text { Time, } \\
\min \end{array}$ & $\begin{array}{l}\text { Total } \\
\text { Vol }\end{array}$ & $\mathrm{H}_{2}$ & ${ }^{3} \mathrm{He}$ & 4 He & InT & $T_{ \pm}$ & $\begin{array}{l}\text { Total } \\
\underline{T}_{2}\end{array}$ & co & $\mathrm{N}_{2}$ & $\mathrm{Ar}$ & $\mathrm{CH}_{4}$ & $\underline{o}_{2}$ & $\mathrm{CO}_{2}$ & $\underline{\mathrm{CO}},+\mathrm{CO}$ \\
\hline \multirow[t]{2}{*}{$\begin{array}{l}17 \\
17 A \\
17 B\end{array}(\mathrm{~b})$} & $\begin{array}{l}4 / 1 / 66 \\
4 / 1 / 66 \\
4 / 1 / 66\end{array}$ & $\begin{array}{c}330 \\
-\end{array}$ & $\begin{array}{r}142 \\
26.5 \\
78.7\end{array}$ & $\begin{array}{l}75.6 \\
0.02 \\
60.2\end{array}$ & $\bar{z}$ & $\begin{array}{l}4.65 \\
-\end{array}$ & $\begin{array}{l}2.47 \\
4.00\end{array}$ & $\begin{array}{l}0.01 \\
0.07\end{array}$ & $\begin{array}{l}1.24 \\
2.07\end{array}$ & $\begin{array}{c}40.5 \\
3.01\end{array}$ & $\begin{array}{r}17.9 \\
0.65 \\
0.21\end{array}$ & $\begin{array}{l}0.44 \\
0.03 \\
-\end{array}$ & $\begin{array}{l}0.27 \\
0.10 \\
0.21\end{array}$ & $0 . \overline{0}$ & $\begin{array}{l}0.28 \\
25.6 \\
11.0\end{array}$ & $\begin{array}{l}40.7 \\
25.6 \\
14.0\end{array}$ \\
\hline & Total & & 247 & 136 & - & 4.65 & 6.47 & 0.08 & 3.31 & 43.5 & 18.8 & 0.47 & 0.58 & 0.05 & 36.9 & 80.4 \\
\hline \multirow[t]{2}{*}{$\begin{array}{l}18 \\
18 \mathrm{~A}(\mathrm{~b}) \\
18 \mathrm{~B}(\mathrm{c})\end{array}$} & $\begin{array}{l}4 / 4 / 66 \\
4 / 4 / 66 \\
4 / 4 / 66\end{array}$ & $\begin{array}{l}290 \\
=\end{array}$ & $\begin{array}{l}565 \\
28.1 \\
50.6\end{array}$ & $\begin{array}{c}104 \\
0.02 \\
41.2\end{array}$ & $\begin{array}{l}\overline{0} \\
0.03\end{array}$ & $\begin{array}{l}3.45 \\
0.04\end{array}$ & $\begin{array}{l}1.19 \\
1.03\end{array}$ & $\begin{array}{l}0.11 \\
0.01 \\
0.01\end{array}$ & $\begin{array}{l}0.70 \\
0.01 \\
0.52\end{array}$ & $\begin{array}{l}408 \\
0.32 \\
1.52\end{array}$ & $\begin{array}{c}45.8 \\
0.31 \\
0.14\end{array}$ & $\begin{array}{l}0.40 \\
0.05 \\
-\end{array}$ & $\begin{array}{l}0.62 \\
0.04 \\
0.07\end{array}$ & $\begin{array}{l}0.11 \\
0.02\end{array}$ & $\begin{array}{r}0.85 \\
27.3 \\
6.50\end{array}$ & $\begin{array}{l}409 \\
27.7 \\
8.02\end{array}$ \\
\hline & Tota1 & & 644 & 145 & 0.03 & 3.49 & 2.22 & 0.13 & 1.23 & 410 & 46.3 & 0.45 & 0.73 & 0.13 & 34.7 & 445 \\
\hline \multirow[t]{2}{*}{$\begin{array}{l}19 \\
19 \mathrm{~A}(\mathrm{~b}) \\
19 \mathrm{~B}(\mathrm{c})\end{array}$} & $\begin{array}{l}4 / 5 / 66 \\
4 / 5 / 66 \\
4 / 5 / 66\end{array}$ & $\begin{array}{l}270 \\
-\end{array}$ & $\begin{array}{l}555 \\
20.7 \\
32.3\end{array}$ & $\begin{array}{l}65.5 \\
0.05 \\
27.9\end{array}$ & $\bar{z}$ & $\begin{array}{l}1.55 \\
-\end{array}$ & $\begin{array}{l}0.50 \\
0.60\end{array}$ & $\begin{array}{l}0.17 \\
0.01 \\
-\end{array}$ & $\begin{array}{l}0.42 \\
0.01 \\
0.30\end{array}$ & $\begin{array}{l}438 \\
0.59 \\
0.56\end{array}$ & $\begin{array}{r}48.2 \\
0.36 \\
0.21\end{array}$ & $\begin{array}{l}- \\
0.05 \\
0.01\end{array}$ & $\begin{array}{l}0.61 \\
0.06 \\
0.05\end{array}$ & $\begin{array}{l}0.61 \\
0.06 \\
0.06\end{array}$ & $\begin{array}{r}0.22 \\
19.5 \\
2.80\end{array}$ & $\begin{array}{r}438 \\
20.1 \\
3.46\end{array}$ \\
\hline & Total & & 608 & 93.5 & - & 1.55 & 1,10 & 0.18 & 0.73 & 439 & 48.8 & 0.06 & 0.72 & 0.73 & 22.5 & 462 \\
\hline \multirow[t]{2}{*}{$\begin{array}{l}22 \\
22 \mathrm{~A} \\
22 \mathrm{~B}\end{array}\left(\begin{array}{l}\mathrm{b} \\
\mathrm{c}\end{array}\right)$} & $\begin{array}{l}4 / 19 / 66 \\
4 / 19 / 66 \\
4 / 19 / 66\end{array}$ & $\begin{array}{c}325 \\
=\end{array}$ & $\begin{array}{c}158 \\
12.8 \\
26.3\end{array}$ & $\begin{array}{c}114 \\
0.07 \\
22.1\end{array}$ & $\bar{z}$ & $\begin{array}{c}\overline{-} \\
0.01\end{array}$ & $\begin{array}{l}0.44 \\
-0.29\end{array}$ & $\bar{z}$ & $\begin{array}{l}0.22 \\
-.15\end{array}$ & $\begin{array}{c}42.8 \\
0.33 \\
0.94\end{array}$ & $\begin{array}{l}0 . \\
0.20 \\
0.34\end{array}$ & 0.01 & $\begin{array}{l}0.16 \\
0.06 \\
0.07\end{array}$ & $\begin{array}{l}0.06 \\
0.01 \\
-\end{array}$ & $\begin{array}{r}0.13 \\
12.1 \\
2.55\end{array}$ & $\begin{array}{c}42.9 \\
12.4 \\
3.49\end{array}$ \\
\hline & Tota1 & & 197 & 136 & - & 0.01 & 0.73 & - & 0.37 & 44.1 & 0.54 & 0.01 & 0.29 & 0.07 & 14.8 & 58.8 \\
\hline
\end{tabular}

Fun 17 - 304L cruc1ble conta1n1ng unirradiated target.

Run 18 - Carbon steel orucible contalning unirradiated target.

Run 19 - Empty carbon steel crucible.

Run 22 - Empty 304L cmucible.

(a) Columins 10 and 17 not 1ncluded.

(b) Gas evolved frum trap when thawed to room temperature.

(c) Gas passing through uranium decomposer wh1le heat1ng trap to about $100^{\circ} \mathrm{C}$. 


\section{TABLE XIV}

Run 21: Gases Evolved from Irradiated Target at $750^{\circ} \mathrm{C}$ for 11. Hours - 304L Stalnless Steel Cruodble

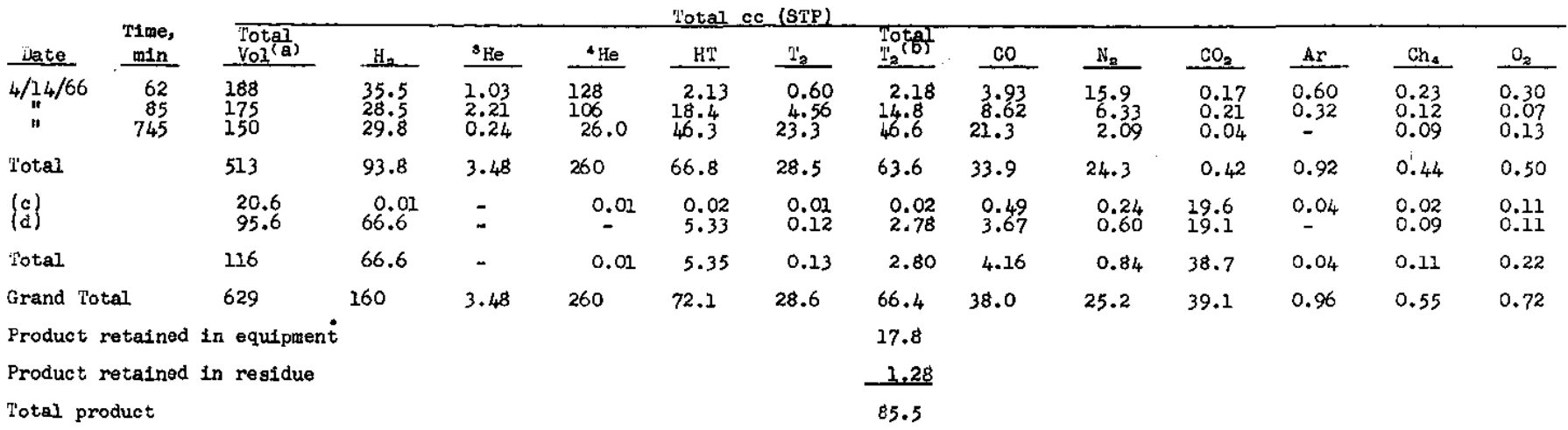

(a) Colum 9 not 1ncluded.

(b) Includes $1 / 2$ the He found.

(d) aees evived rome cold trap due to thams.

passing gases through a urantum decomposer at $550^{\circ} \mathrm{C}$. 


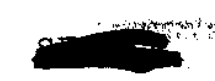

$-24-$

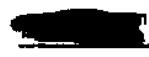




\section{APPENDIX B}

\section{EXTRACTION OF TRITIUM FROM LITHIUM ALUMINATE TARGETS USING FLUX}

A considerable amount of work was done at the Savannah River Laboratory to evaluate the process proposed by Pacific Northwest Laboratory for the extraction of tritium from lithium aluminate targets by dissolution in molten $\mathrm{Na}_{2} \mathrm{~B}_{4} \mathrm{O}_{7}$ at $850^{\circ} \mathrm{C}$. Although a flux was found not to be necessary, this work is of interest and is summarized in this Appendix.

In the proposed fluxing process, shown in Figure 5, the aluminum-clad targets are charged to the furnace with dehydrated sodium tetraborate in a weight ratio of $20 \%$ targets to $80 \%$ f'lux.

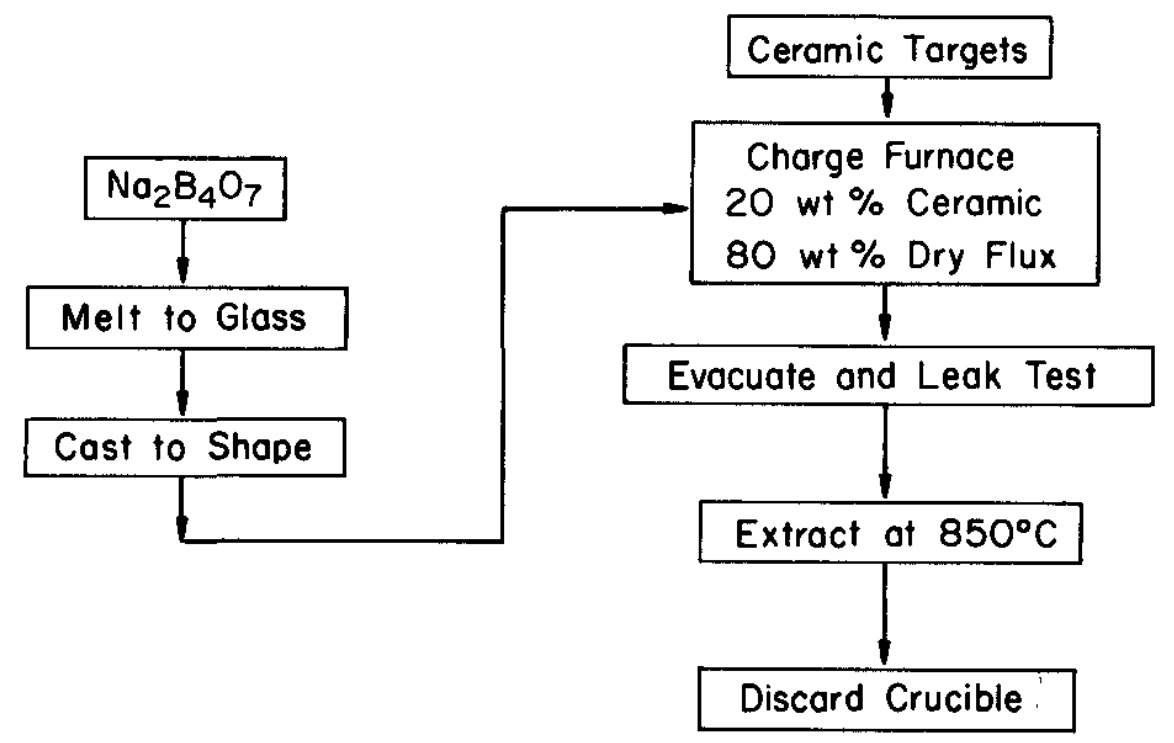

FIG. 5 PROPOSED FLOWSHEET FOR EXTRACTION PROCESS WITH FLUX

As the temperature of the evacuated furnace is increased to $850^{\circ} \mathrm{C}$, some of the tritium is evolved when the cladding melts; this is elemental tritium which is released even at room temperature if the cladding is punctured. The remalnder of the tritium slowly evolves as the flux dissolves the target. The cruclble containing the residue is then buried. Significant information obtained from experiments with both irradiated and unirradiated targets to demonstrate the proposed process is discussed below. 


\section{Successful Dissolution}

Dissolution of a $\mathrm{LiAlO}_{2}$ target in four times its weight of molten sodium tetraborate at $850^{\circ} \mathrm{C}$ allows extraction of more than $98 \%$ of the tritium in 20 hours (Runs 9, 11, and 12). No trace of target material was found when the crucibles containing the residues from these runs were cut at two-inch intervals. Ceramic residue was not found on the bottom of the crucibles when the bottom sections were cut along their axes. A plot of the gases evolved during Run 12, shown in Figure 6, indicates that possibly all of the tritium was released from the target during about six hours at $850^{\circ} \mathrm{C}$, as in the case of runs without fiux, and that the remaining time was spent vacuum outgassing the tritium from the metal equipment. Since the dissolution of unirradiated ceramic In flux at $850^{\circ} \mathrm{C}$ was only about $40 \%$ complete in 10 hours, as estimated from the crucible sections of Run 5 in Figure 7, irradiated targets apparently dissolve faster than unirradiated targets.

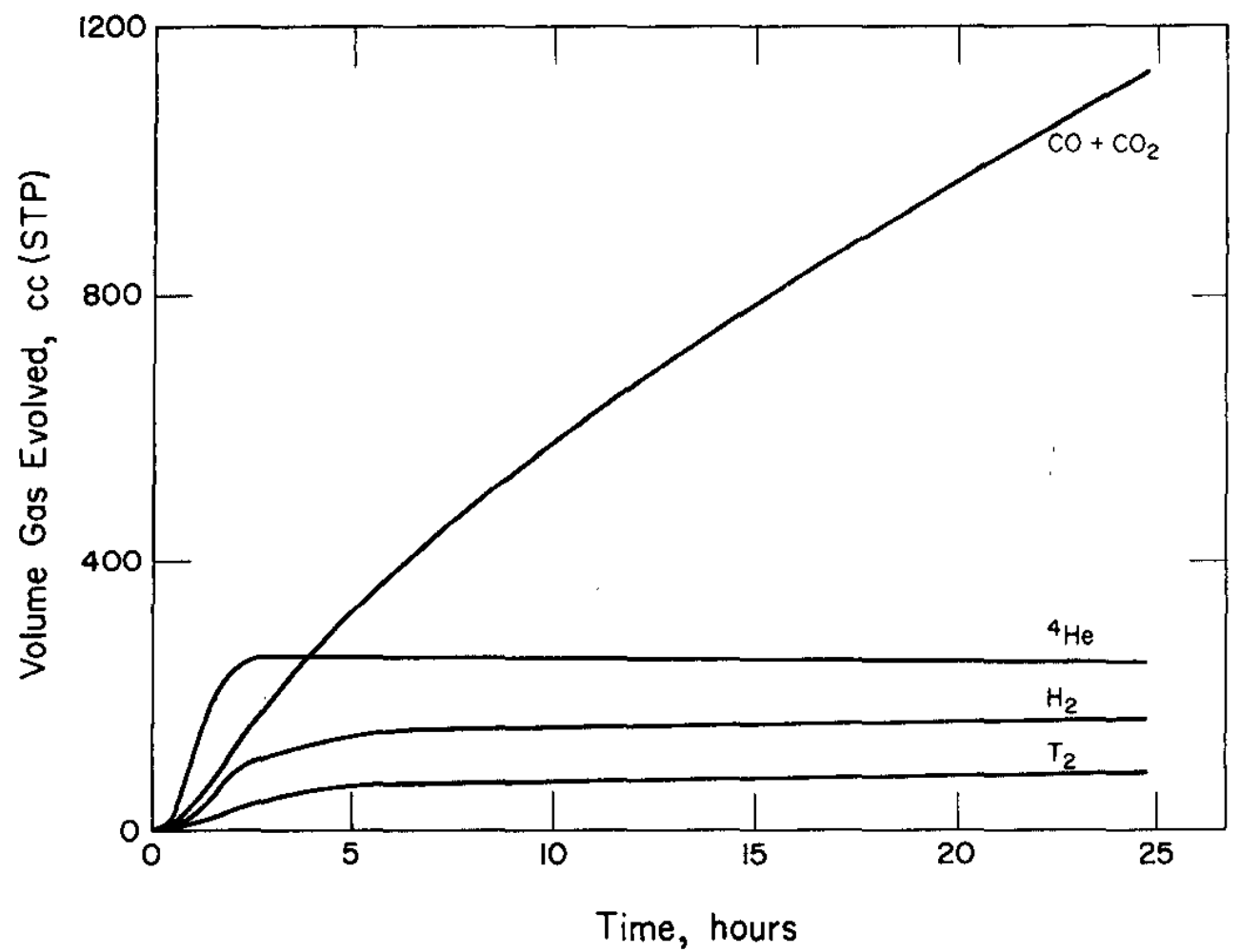

FIG. 6 GASES EVOLVED AT $850^{\circ} \mathrm{C}$ - WITH FLUX (Run 12) 

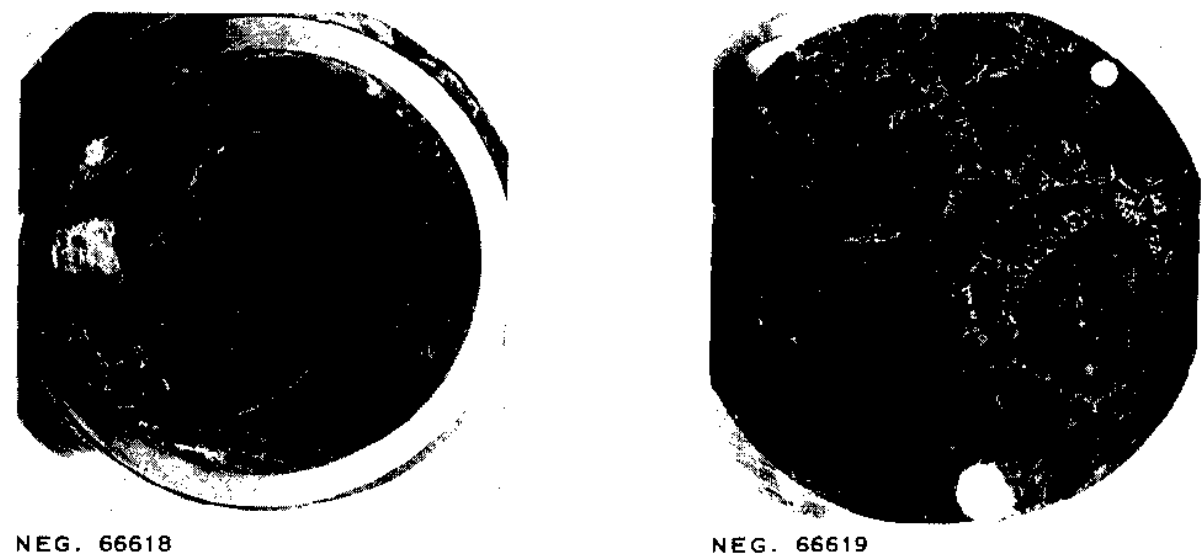

2 Inches from Bottom

4 Inches from Bottom

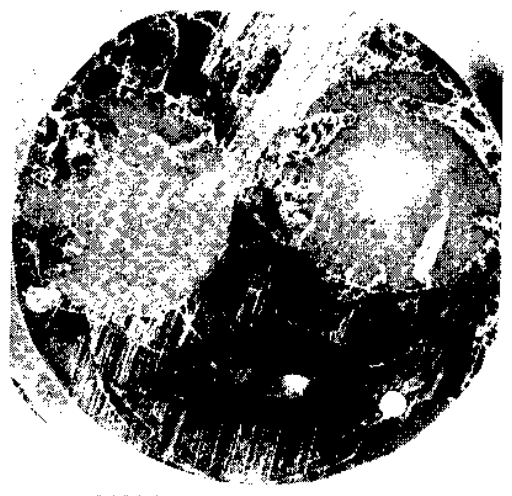

NEG. 66620

5 Inches from Bottom

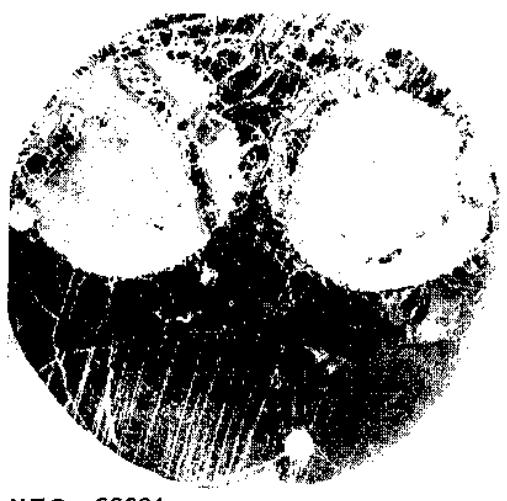

NEG, 66621

6 Inches from Bottom

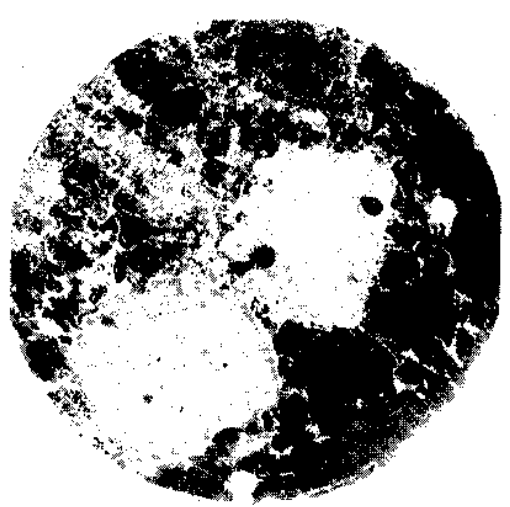

NEG. 66623

8 Inches from Bottom

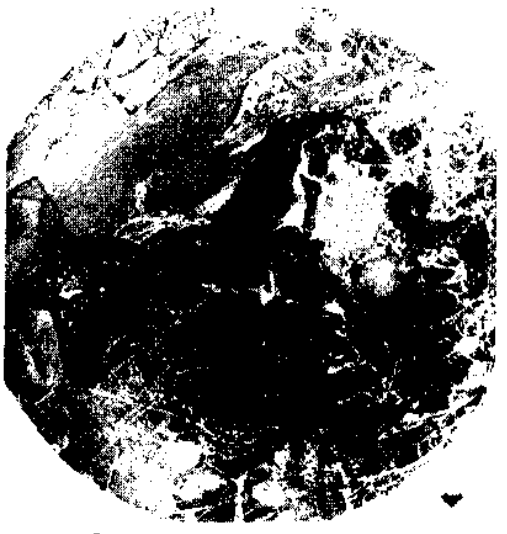

NEG. 66624

9 Inches from Bottom

Ceramic Pellets were Placed in the Crucible Side by Side for a Total of $\sim 5$ Inches, Starting from the Bottom.

FIG. 7 EXTENT OF CERAMIC DISSOLUTION AT END OF RUN 5 


\section{Losses to the Residue}

Analysis of the residues showed that 1 to $2 \%$ of the $T_{2}$ was retalned in the flux and was unextractable (Runs 9, 11 , and 12). Although the samples analyzed were taken from varlous locations in each of the crucibles, they agreed within $1 \%$ for any one run, indicating a uniform concentration. The $\mathrm{T}_{2}$ is probably retained by exchange with the traces of water remaining in the flux.

\section{Suspending Targets}

The targets must be suspended off the bottom of the crucible in order to unfformly dissolve the $\mathrm{LIAlO}_{2}$ in flux. Otherwise the dissolution rate of the ceramic on the bottom of the crucible will decrease as the denser flux containing dissolved $\mathrm{LIAlO}_{2}$ settles to the bottom. Figure 8 shows the remains of a target after 10 hours at $850^{\circ} \mathrm{C}$ in flux (Run 4). The crucible and most of the flux has been removed from the ceramic residue except for the bottom 1 inch. The bottom 4 inches of ceramic dissolved much slower than the remainder of the target. Suspending the target on a grate 4 inches above the bottom of the crucible gave a much more uniform dissolving rate (Figure 7 ).

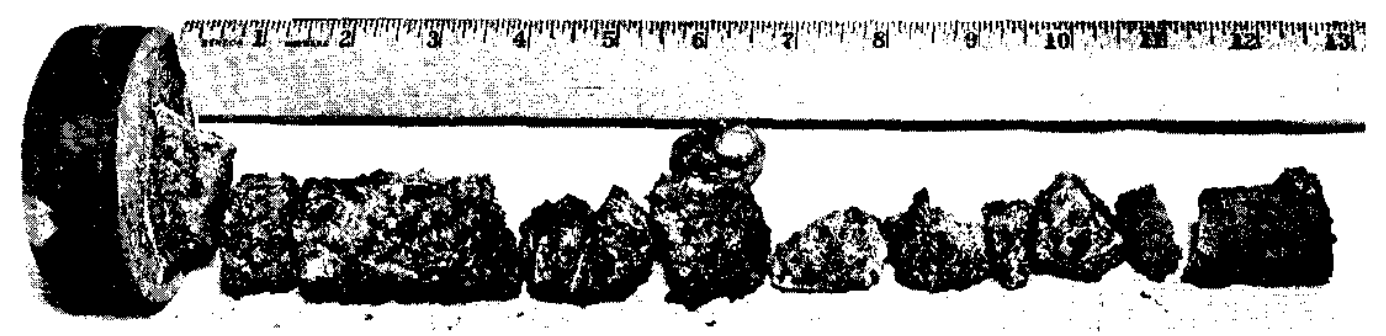

NEG. 9522

FIG. 8 EXTENT OF CERAMIC DISSOLUTION AT END OF RUN 4

\section{Evolution of $\mathrm{H}_{2}, \mathrm{CO}$, and $\mathrm{CO}_{2}$}

As shown in Table IV, during the extraction of tritium with untreated flux, $9 \mathrm{GVR}$ of $\mathrm{H}_{2}$ and $12 \mathrm{GVR}$ of $\mathrm{CO}+\mathrm{CO}_{2}$ are also evolved (Run 8). Pretreating the flux at $850^{\circ} \mathrm{C}$ for 11 hours in a vacuum reduced the $\mathrm{H}_{2}$ and $\mathrm{CO}+\mathrm{CO}_{2}$ evolution to about 1.5 and $7.0 \mathrm{GVR}$, respectively (Runs 11 and 12). Continued vacuum drying of the flux at $850^{\circ} \mathrm{C}$ removed very little additional water, as interpreted in Figure 9 from the data of Run 2. Attempts to pretreat at $1000^{\circ} \mathrm{C}$ caused the flux to decompose (Figure 10). All of these experiments with flux were conducted in carbon steel crucibies. 


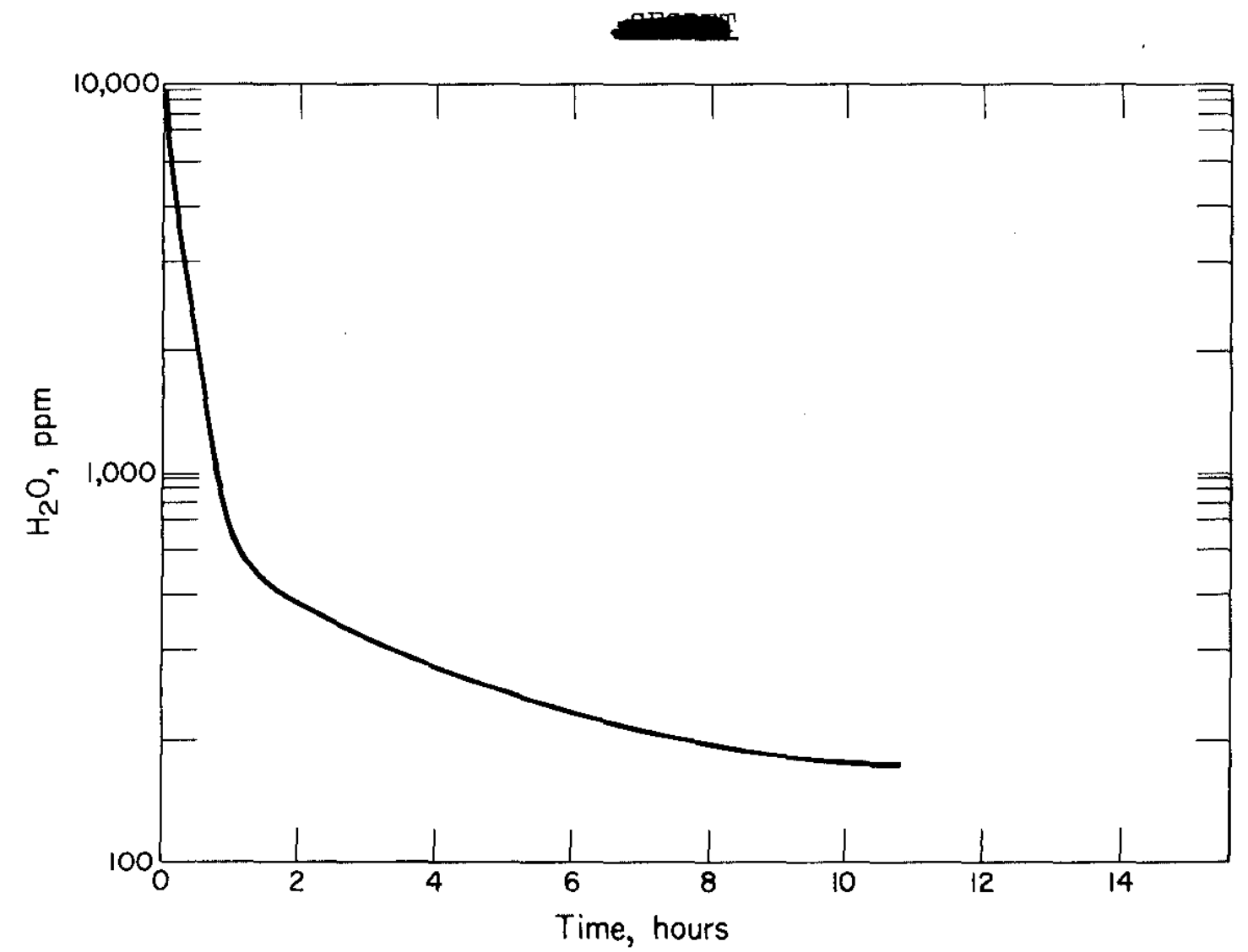

FIG. $9 \mathrm{H}_{2} \mathrm{O}$ LEFT IN $\mathrm{Na}_{2} \mathrm{~B}_{4} \mathrm{O}_{7}$ AS A FUNCTION OF TIME AT $850^{\circ} \mathrm{C}$ IN A VACUUM

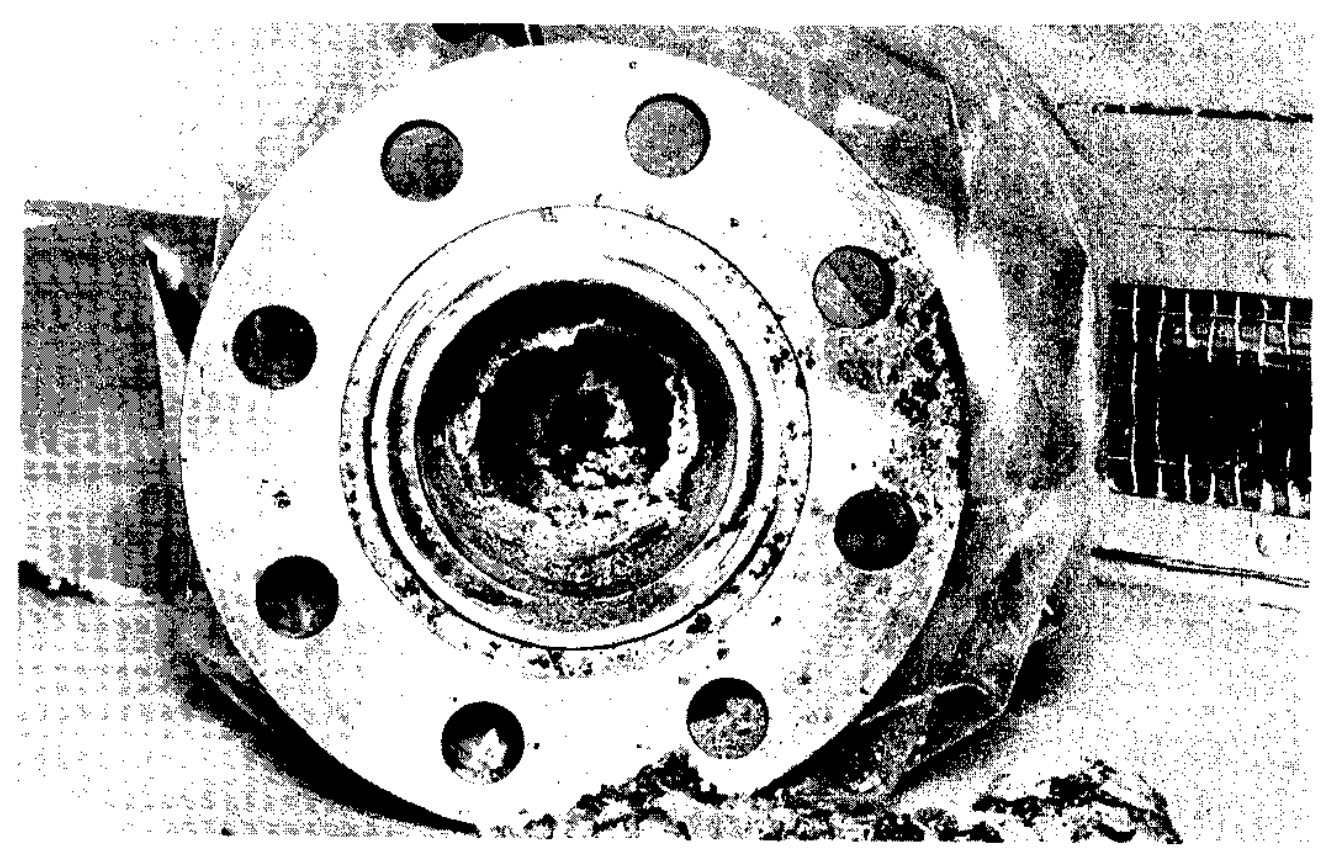

NEG. 9460

FIG. 10 INTERNAL VIEW OF FURNACE SHOWING DECOMPOSED $\mathrm{Na}_{2} \mathrm{~B}_{4} \mathrm{O}_{7}$ 
The later realization that the crucibles add both carbon oxides and water in the amounts suggested by Table III has not been included in the data; e.g., approximately 2.5 GVR of $\mathrm{CO}$ and $\mathrm{CO}_{2}$ should be subtracted from the total as the contribution from the carbon steel crucible.

\section{Corrosion}

The maximum corrosion rate of both the stainless steel and carbon steel crucibles was about $5 \mathrm{mils}$ in 20 hours, close to that observed by PNL; no localized attack was observed.

\section{HTO AND $\mathrm{T}_{2} \mathrm{O}$}

As observed in Runs 8 and 11, 75\% of the tritium is evolved as water vapor when untreated flux is used, whereas pretreating the flux reduces the fraction to 40\%; this vapor can be readily decomposed by hot uranium chips.

\section{Use of Lower Ratio of Flux to Ceramic}

One run was made (Run 6) using a flux-to-ceramic ratio of 2 instead of the usual 4. The amount of ceramic material dissolved or severely attacked by the flux varled considerably depending upon the location of the ceramic in the cruclble, as shown in Figure 11. There was a large vold around the top three inches of ceramic material thus accounting for the low dissolution rate at that location. The initial release of gases from the target probabiy acted as an air lift and moved some of the flux Into the top, cold, region of the furnace where it solidified. The poor dissolution over the bottom 3 inches indicates again the need for suspending the material off the bottom of the crucible. The results of this run emphasized that a flux-to-ceramic ratio of 4 is necessary to ensure that the targets w1ll be completely surrounded by molten flux.

\section{Analyses of Sodium Tetraborate}

A variety of chemical analyses were used to confirm that:

- The decomposition products of the sodium tetraborate which was heated to $1000^{\circ} \mathrm{C}$ (Run 2d) in vacuum included metallic sodium. 

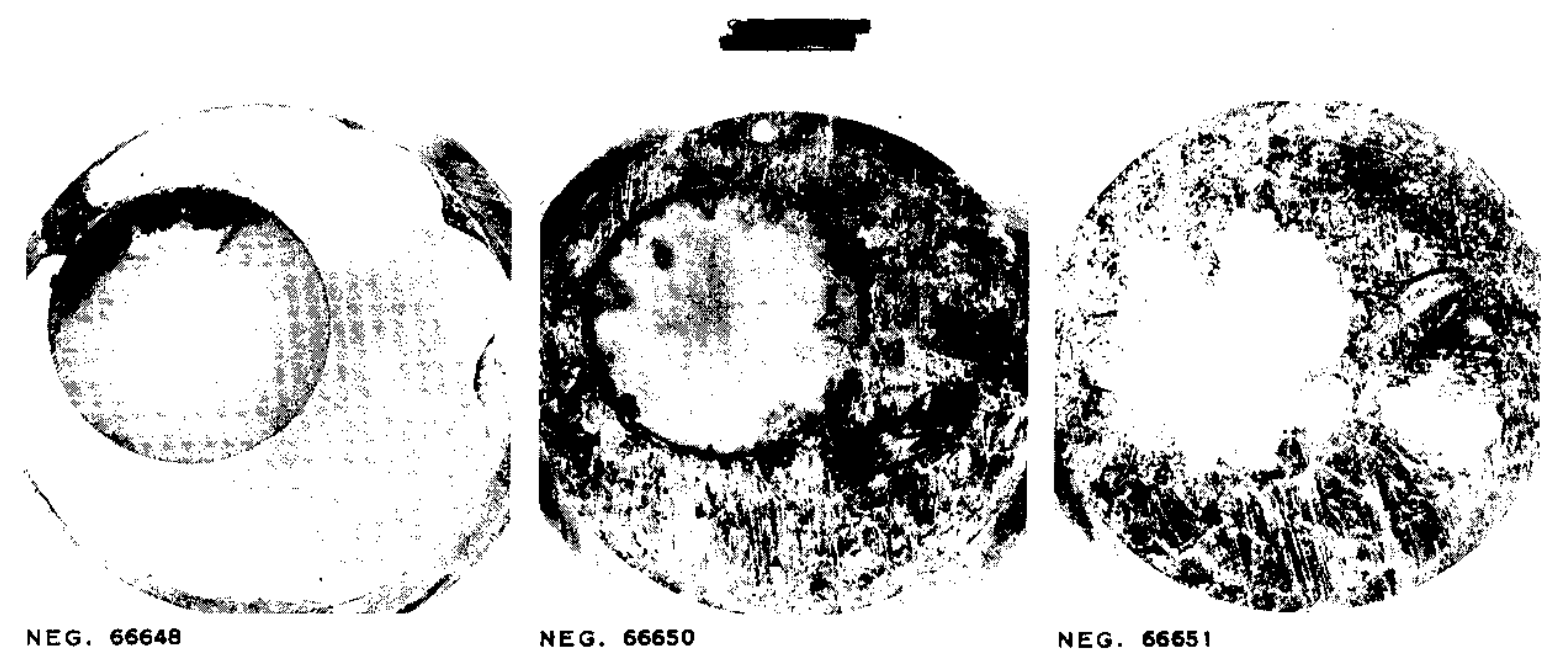

3 Inches from Bottom

NEG. 66651

4 Inches from Bottom
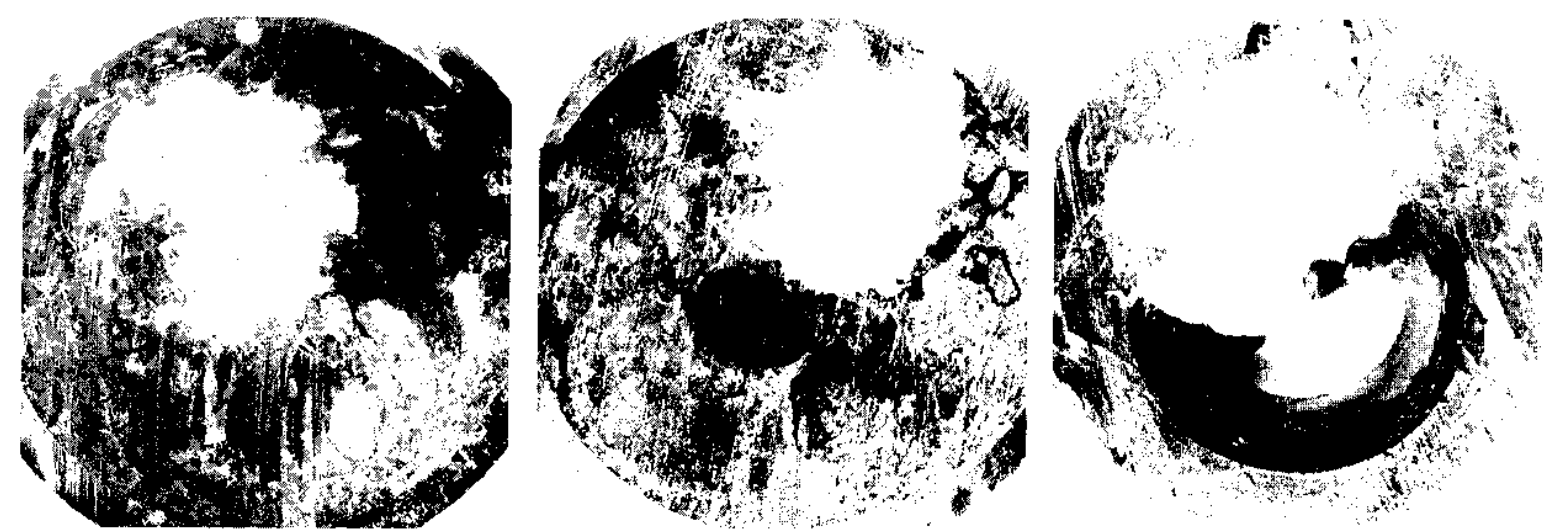

NEG. 66653

NEG. 56655

8 Inches from Bottom

NEG. 66657

10 Inches from Bottom

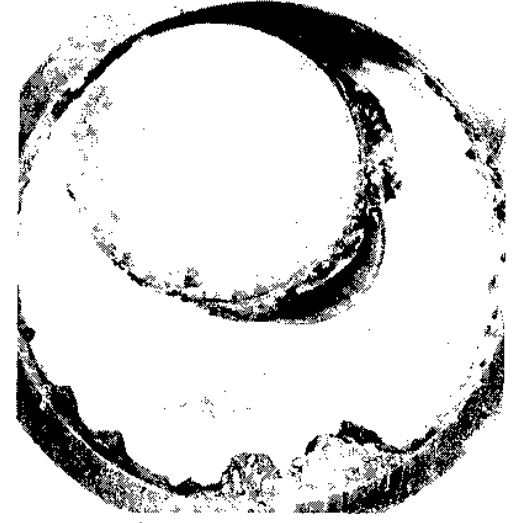

NEG. 66659

12 Inches from Bottom

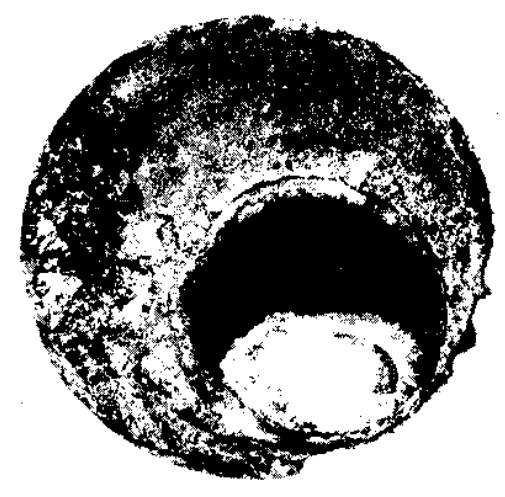

NEG- 66660

13 Inches from Bottom

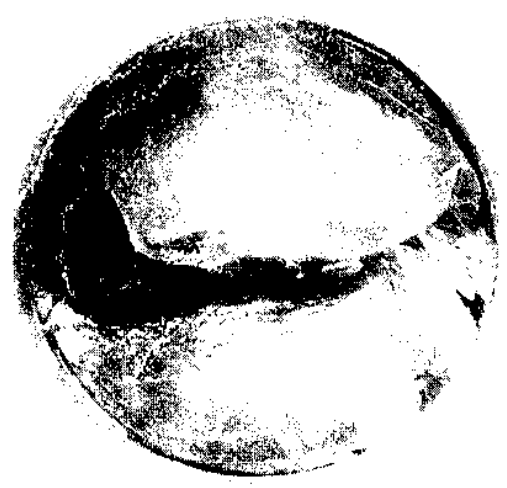

NEG. 66661

View from Top of Crucible

FIG. 11 EXTENT OF CERAMIC DISSOLUTION AT END OF RUN 6 
- The "anhydrous" $\mathrm{Na}_{2} \mathrm{~B}_{4} \mathrm{O}_{7}$ contains approximately $1 \%$ water that is released between 850 and $1000^{\circ} \mathrm{C}$, and contains unstable impurities that liberate significant quantities of $\mathrm{CO}_{2}, \mathrm{CO}$, and $\mathrm{H}_{2}$.

- There is no selective leaching of lithium from Iithium-aluminate targets by the $\mathrm{Na}_{2} \mathrm{~B}_{4} \mathrm{O}_{7}$ fiux.

- The carbon content of $\mathrm{Na}_{2} \mathrm{~B}_{4} \mathrm{O}_{7}$ from several sources varied from 25 to $350 \mathrm{ppm}$.

\section{Disadvantages of Using Flux}

There appear to be no advantages in using flux to extract tritium from lithium aluminate to offset the numerous disadvantages listed below:

- The loss of tritium to the flux will run between 1 and $2 \%$ compared to $<0.1 \%$ extracting without flux.

- $\mathrm{Na}_{2} \mathrm{~B}_{4} \mathrm{O}_{7}$ which is low in molsture content may be difflcult to obta1n; new equipment and techniques would be required for charging the flux to the production furnace.

- The capacity of a furnace charge is reduced markedly by the large volume occupled by the flux.

- The amount of water vapor evolved when using flux is many times greater than without flux, thus requiring additional uranium decomposers.

- The amount of $\mathrm{CO}+\mathrm{CO}_{2}$ evolved during the extraction of tritium with flux is at least 10 times greater than without flux. 